\title{
CIDADE DIVIDIDA: SOROCABA E O ZONEAMENTO URBANO DE 1914
}

\section{CITY DIVIDED: SOROCABA AND THE ZONING OF 1914}

\author{
Ana Maria Reis de Goes Monteiro ${ }^{1}$ \\ Thiago Pedrosa Mattos ${ }^{2}$
}

\section{Resumo}

A proposta deste trabalho é apresentar características da distribuição de água, esgoto e iluminação pública no início do século XX em Sorocaba-SP. Essa sugestão é justificável por pertencer a um complexo significativo, pois envolve a promulgação de uma normatização legislativa no município acerca da divisão do perímetro urbano em duas zonas no ano de 1914, datação que permite ampliar a questão dos debates acadêmicos acerca das leis de zoneamento no Brasil. Dessa forma, cabe salientar que a metodologia de estruturação da narrativa do trabalho conduziu uma abordagem que buscou estabelecer fundamentos da questão municipal em consonância com regulamentações normativas do Estado de São Paulo e da União para o período, além de promover um diálogo acerca das possíveis dissidências existentes entre os discursos proferidos e as práticas realizadas, materializados pela revisão bibliográfica e análise de Livros da Câmara Municipal. Sendo assim, espera-se que o presente artigo traga novas informações ao debate acerca da distribuição de recursos públicos no início do período Republicano, assim como a divisão dos espaços urbanos de uma localidade específica. Em termos conclusivos, cabe ressaltar que a legislação de zoneamento sorocabana (1914) pode ser considerada pertencente ao universo pioneiro acerca do assunto referido em uma escala nacional.

Palavras-chave: Sorocaba; zoneamento urbano; água; esgoto; iluminação pública.

\begin{abstract}
The purpose of this paper is to present the distribution characteristics of water, sewerage and public lighting in the early twentieth century in Sorocaba-SP. This suggestion is justifiable to belong to a significant complex because it involves the enactment of a legislative regulation in the municipality about the urban perimeter split into two areas in 1914, dating that enable enlarge of academic debates about the zoning laws in Brazil. Thus, it should be noted that the work of narrative structuring methodology conducted an approach that sought to establish foundations of municipal issue in line with normative regulations of the State of São Paulo and the Union for the period, and to promote a dialogue about possible dissent existing between the speeches and the practices carried out, performed by literature review and analysis of books of the City Council. Thus, it is expected that this Article bring new information to the debate on the distribution of public funds in the early Republican period, and the division of urban spaces in a specific location. In conclusive terms, it is worth noting that the Sorocaba zoning law (1914) may be considered to belong to the pioneer universe on the above subject on a national scale.
\end{abstract}

Keywords: Sorocaba; zoning; water; sewer; public lighting.

\footnotetext{
1 Doutorado pela Faculdade de Engenharia Civil, Arquitetura e Urbanismo da Universidade Estadual de Campinas. Professora doutora no curso de Arquitetura e Urbanismo da Universidade Estadual de Campinas Unicamp. Representante da UNICAMP no Conselho Municipal de Desenvolvimento Urbano de Campinas CMDU e no CMU - Centro de Memória da Unicamp. Diretora da ABEA - Associação Brasileira de Ensino de Arquitetura e Urbanismo.E-mail: anagoes@fec.unicamp.br

${ }^{2}$ Mestrando na área de Teoria, História e Métodos em Arquitetura e Urbanismo - do Programa de PósGraduação em Arquitetura, Tecnologia e Cidade - da Faculdade de Engenharia Civil da Universidade Estadual de Campinas (UNICAMP). E-mail: thiagohstr@gmail.com
} 


\section{INTRODUÇÃO}

O objetivo deste trabalho é abordar o assunto da distribuição de água, esgoto e iluminação pública em Sorocaba, utilizando-se de fontes da Câmara Municipal acerca da divisão do perímetro urbano em zonas, no ano de 1914, e da cobrança de Impostos Prediais e de Viação no ano de 1916.

O que justifica a intenção deste trabalho é a possibilidade de contribuir ao debate da questão legislativa do zoneamento urbano no Brasil, resgatando-se fontes específicas que podem trazer novas tônicas à gênese desse fenômeno urbanístico.

A estrutura deste trabalho está dividida em 4 partes. A primeira faz um retrospecto da Constituição da República (1891), Constituição do Estado de São Paulo (1891) e legislações específicas estaduais, sob uma perspectiva da questão dos municípios. O segundo momento resgata aspectos sociais e políticos da cidade de Sorocaba na virada do século XX, bem como a condução da estruturação urbana e a distribuição de água, esgoto e iluminação no município da década de 1910. Em terceiro lugar, há espaço ao debate epistemológico, envolvendo o relacionamento acerca de discursos e práticas, sob um viés teórico e demonstrativo da proposta central do objetivo. E, por fim, há uma observação acerca de ideias acadêmicas importantes que se dedicaram à questão da divisão do território urbano, bem como elementos que fundamentam o debate das regulamentações de zoneamento no Brasil do início do século XX.

\section{Nasce a primeira Constituição brasileira republicana: fevereiro de 1891}

Na promessa de organizar um regime livre e democrático, a Constituição da República dos Estados Unidos do Brasil foi promulgada em 24 de fevereiro de 1891.

Texto conciso e feito de maneira rápida. "É a Carta mais enxuta da nossa história"; ; feita às pressas, notou a historiografia de Marco Antonio Villa (2011), posto que os constituintes estavam amedrontados com a epidemia de febre amarela que assombrava a população carioca no verão de 1891.

Acerca dos assuntos municipais, estabelecia, por exemplo, normatizações que permitiam autonomia regional. Regulamentava, com o Art. 68, uma hierarquização institucional para isso, em que: "Os Estados organizar-se-ão de forma que fique assegurada a autonomia dos Municípios em tudo quanto respeite ao seu peculiar interesse ${ }^{4 \prime}$. Exemplo prático dessa hierarquização é

\footnotetext{
${ }^{3}$ VILLA, 2011, p.32

${ }^{4}$ BRASIL. Constituição da República dos Estados Unidos de, 1891.
} 
encontrado no art. 9o da Constituição (1891), ao qual estabelecia a regulamentação acerca da taxação de impostos de propriedade - elemento de poder nos municípios - como responsabilidade dos Estados.

Além dessas configurações normativas - que servirão como ferramental de análises, neste trabalho - cabe ressaltar que a Constituição da República (1891) também dispunha acerca do fim de privilégios vinculados ao período nobiliárquico, em desdobramento do $§ 2^{\circ}$, Art. 72 , no qual afirmava que: "§2ㅇ - Todos são iguais perante a lei $i^{5 " .}$

Essa característica seria prevista, posteriormente, nas promulgações das constituições estaduais, por necessariamente serem marcos vinculados ao regulamento magno da República brasileira. No caso de São Paulo, esse princípio era garantido, constitucionalmente, pelo inciso III do Art. 57ํㅡ, quanto à isonomia e a não admissão de privilégios ${ }^{6}$.

\section{A Constituição republicana paulista de 1891}

A autonomia administrativa era uma das reivindicações mais acaloradas da elite paulista no final do período imperial. É possível perceber em Alberto Sales ${ }^{7}$ (1983) essa reivindicação:

Os municípios, apertados em uma organização acanhada e raquítica, que não Ihes reconhece competência para coisa alguma, ainda mesmo nos assuntos mais triviais de policiamento das cidades, vivem esmagados completamente pela ferrenha centralização do império e só se movem a custo dentro de estreitos limites de uma organização absurda e intolerável, sem nem ao menos possuírem o direito de organizar por si mesmos os seus orçamentos ${ }^{8}$.

Após a proclamação republicana e promulgação constitucional, a elite política de

São Paulo não tardou em publicar a Carta regulamentadora estadual.

No art. 3ํ, a entidade municipal é estabelecida enquanto base estadual autônoma? Caberia ao Estado promover esse direito.

Importante observar que o art. 53ㅇ, além de garantir a liberdade governamental, preestabelecia a independência econômica do município ${ }^{10}$, demonstrando-se que a regulamentação federal e estadual atendiam, em partes, reivindicações antigas do Partido Republicano Paulista.

\footnotetext{
${ }^{5}$ Ibidem.

${ }^{6}$ São Paulo, Constituição do Estado de, 1891.

${ }^{7}$ Teórico do Partido Republicano Paulista no final do século XIX. Ver em: http://www.cdpb.org.br/dic_bio_bibliografico_sales joao.html

${ }^{8}$ SALES, 1983, p.48.

${ }^{9}$ SÃO PAULO. Constituição do Estado de, 1891.

${ }^{10}$ Ibidem.
} 


\section{Lei Estadual N 1.038, de 19 de dezembro de 1906}

A Lei n. 1.038/1906, promulgada durante a presidência estadual de Jorge Tibiricá, trazia uma novidade importante: organizava o poder executivo municipal pela eleição de prefeitos ${ }^{11}$, conforme estipulava o art. 5‥ Anteriormente, o cargo executivo era eleito indiretamente, por intermédio dos vereadores diplomados à Câmara Municipal, ao qual nomeavam o Intendente, conforme o Art. 16 da lei n. 16/1891 12 .

Outro aspecto importante da lei n. 1038/1906 estava estabelecido no art. 19, relacionado à receita municipal. Destacam-se, aqui, os incisos 20 e 12 , por respectivamente atenderem ao recorte proposto acerca das questões abordadas neste trabalho:

Artigo 19. - A receita dos municipios será constituída somente das seguintes verbas:

2. Do imposto de industrias e profissões, e do imposto predial urbano nas localidades em que este couber às municipalidades;

12. Das taxas de viação, comprehendendo calçadas, terrenos em aberto, cercas, guias, e falta de encanamento nos predios urbanos para aguas pluviaes ${ }^{13}$;

Esse dispositivo jurídico foi importante para os municípios paulistas. No caso, para este trabalho, será analisada a situação de Sorocaba, cidade localizada no interior do Estado, que, como outras, utilizou esses recursos para a arrecadação de rendas municipais. Além do mais, a dinâmica na cobrança local permitiu uma configuração inusitada para a época: a divisão do espaço urbano em duas zonas, o que endossa a justificativa acerca das motivações em debater a questão.

A promulgação da Lei n. 1.038/1906 previa, no Art. 3ํ das disposições transitórias, que os municípios deveriam se adequar às normatizações estaduais. No caso de Sorocaba, essa condição foi possível em 1914, com a publicação de novas leis e Posturas municipais ${ }^{14}$.

Ao longo dos 8 anos que antecederam as referidas adequações (1906-1914), as normas da municipalidade sorocabana estavam fundamentadas, principalmente, acerca da higiene pública, disciplinarização e regulamentação do espaço urbano e da dimensão das edificações ${ }^{15}$, em um conjunto de normatizações legislativas urbanísticas que já engendravam a dinâmica da espacialidade local, que seria reforçada com as disposições futuras, efetivadas em 1914.

${ }^{11}$ SÃO PAULO. Lei N. 1.038, de 19 de Dezembro de 1906. Dispõe sobre a organização municipal. Diario Official do Estado de São Paulo. São Paulo, n. 17 de 20 de Janeiro de 1907.

12 SÃO PAULO. Lei N. 16, de 13 de Novembro de 1891.

${ }^{13}$ Ibidem, p. 222-3

${ }^{14}$ Codificação das Leis da Camara Municipal de Sorocaba (1914-1915). Sorocaba: Typographia Quinze de Novembro, 1915.

${ }^{15}$ Codificação das Leis da Camara Municipal de Sorocaba. São Paulo: Duprat \& Comp., 1906.

Revista de Direito da Cidade, vol. 07, no 4. Número Especial. ISSN 2317-7721 pp.1791-1824 1794 


\section{Mapa 1 - Representação cartográfica de Sorocaba na virada do século XX}

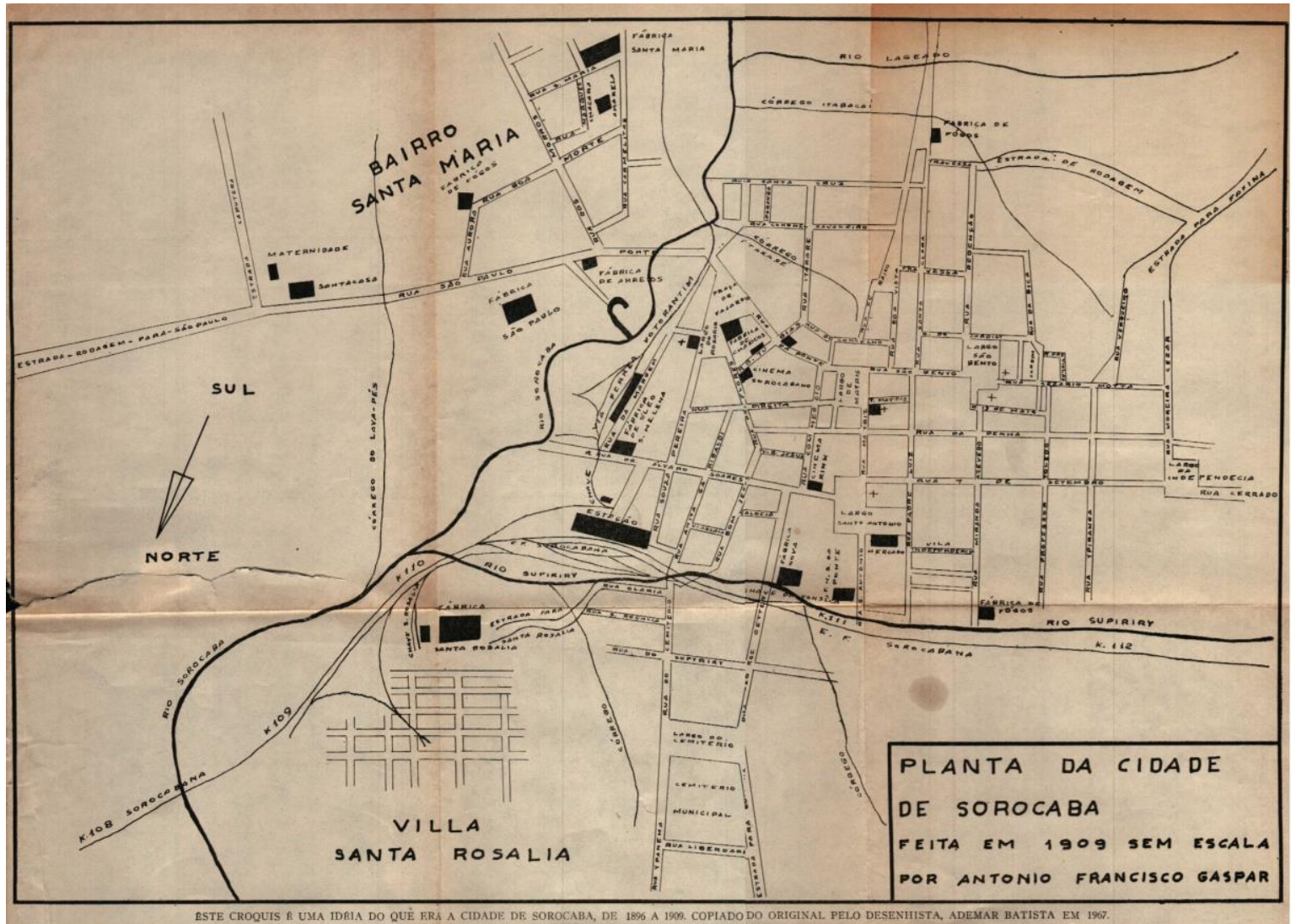

GASPAR, 1967, s/p.

\section{Política, sociedade e cidade: Sorocaba na virada do século XX}

A participação popular na proclamação da República foi algo arranjado, porém não se percebe o mesmo comportamento nos momentos subsequentes do regime; alvo de manifestações e greves; fatos importantes narrados pela historiografia de José Murilo de Carvalho (1987) ${ }^{16}$. Em Sorocaba, o início da República não foi diferente. Foi marcado por agitações grevistas ${ }^{17}$ em um contexto social bastante turbulento. Porém, mesmo com crises políticas e epidemias ${ }^{18}$ de febre amarela, a cidade conseguiu organizar uma industrialização de grande porte ${ }^{19}$.

\footnotetext{
${ }^{16}$ CARVALHO, 1987, p.70.

${ }^{17}$ CARMO, 2007.

18 Em uma publicação científica em medicina, Rita de Cássia Barata esclarece que em momentos de transformações econômicas e crises sociais há mais suscetibilidade à vulnerabilidade epidêmica dos povos, porém ressalta que surtos são comuns na História da humanidade. BARATA, 1987, p.9.

${ }^{19}$ MASSARI, 2011.
} 
Acerca dos vestígios de época, é ilustrativo um relato encontrado no Almanach de Sorocaba para 1903:

Depois da proclamação da Republica os pricipaes acontecimentos que se desenrolaram em Sorocaba, foram os sucessos de 16 de Dezembro de 1892 em que uma revolução popular depoz a camara que se conservara fiel ao governo do dr. Americo Brasiliense; a organisação do Governo dos Atiradores, associação em que se contava cerca de oitenta cidadãos da nossa melhor sociedade, os quaes, perfeitamente disciplinados e armados, prestaram sob o comando do seu illustre instructor, o dr. Alvaro Soares, relevantes serviços á causa da republica por occasião da revolta de 6 de Setembro; a mobilisação da guarda nacional, por occasião da mesma revolta, tendo partido desta cidade para Apiahy um contingente de 50 praças, de infanteria sob o commando do capm. Manoel Januario de Vasconcellos, auxiliado pelos alfs. José Wagner, João Rodrigues e Isaac Pacheco, um outro para Assunguy, sob as ordens dos alfs. Manoel P. dos Reis Junior e Josino Loureiro e um, de cavallaria para Itararé, sob as ordens do alfs. Carmo Barra; a inauguração do grupo escolar, graças aos esforços do distincto sorocabano, o fallecido tent. Antonio Egydio Padilha, a 13 de Agosto de 1895; a primeira epidemia de febre amarella de Abril a Julho de 1897; a inauguração do novo edificio do hospital, em primeiro de Janeiro de 1900; a tremenda epidemia de 1900 e a inauguração das obras do saneamento da cidade no anno de 1901, graças aos esforços do cor. Fernando Prestes de Albuquerque, que, como presidente do estado no tempo da epidemia, solicitou do congresso os créditos precisos para o importante trabalho e do nosso distincto conterraneo dr. Luiz Nogueira Martins que, junto ao governo, envidou todos os esforços para conseguir o grande melhoramento que nos deve pôr a salvo do flagello que enluctou Sorocaba ${ }^{20}$.

Há, ao menos, 4 elementos importantes ocorrentes no início da República, que influenciariam em desdobramentos nessa cidade do início do século XX. Por exemplo, a questão militarista é observável no trecho inicial, aproximando-se da característica do período da "República da Espada", na qual os militares se destacavam politicamente. Posteriormente, observase a questão escolar, o que será importante considerar em Sorocaba, em virtude da característica industrial do local, visto o relacionamento entre educação pública e trabalho da época ${ }^{21}$. E, por fim, a questão da salubridade e higiene pública, refletida sob um contexto de epidemia de febre amarela e a necessidade de saneamento na cidade, de forma a distribuir, mediante redes de água e esgoto, uma condição mais favorável ao progresso que se desejava, e à possibilidade de aniquilação dos males mortíferos epidêmicos; o novo edifício do hospital também auxilia a compreender essa questão. Um discurso que ressoo na voz da mentalidade desenvolvimentista -

\footnotetext{
${ }^{20}$ SILVA, 2007, p.63.

${ }^{21}$ Em 1921, por exemplo, no Grupo Escolar "Senador Vergueiro", de 534 alunos matriculados, 499 eram filhos de operários, sendo 252 estrangeiros, conforme resultado de pesquisa publicada pelos autores SANDANO, W; FERREIRA, V., 2007, p.177.
} 
uma versão regionalizada do Destino Manifesto - foi proferido pelo superintendente da Estrada de Ferro Sorocabana em 1906, na inauguração dos trabalhos que construiriam a represa de Itupararanga. Na fúria da dinamitação das primeiras pedras e na empolgação do acontecimento, Alfredo Maia prenunciou o que o capital industrial liberal ${ }^{22}$ esperava:

O sr. dr. Alfredo Maia, respondendo uma saudação feita em nome do povo, disse que á Sorocaba está reservado um futuro prospero e próximo; que Sorocaba, pela importancia de sua industria, será a Manchester brazileira ${ }^{23}$.

Essa ideia industrializante serviu de lenha ao imaginário social. Já em 1914, por exemplo, Sorocaba tinha um parque industrial têxtil consolidado, de volume produtivo considerável ${ }^{24}$.

Toda a estrutura para que essa realidade fosse possível foi complexa e derivada de processos históricos, mas esteve ligada à rede de vias de comunicação ${ }^{25}$ e desenvolvimento técnico da cidade ${ }^{26}$, em crescimento desde o período bandeirantista e acelerado pelo ciclo tropeiro, por um momento longo, entre os séculos XVII e XIX.

Mas o progresso trouxe ônus; um grande exemplo: a poluição. O Almanach de Sorocaba para 1903 permite essa ilustrar essa questão: em 1881 o manancial Supiriry já estava poluído, com o provável auxílio das atividades produtivas realizadas pela fábrica têxtil Nossa Senhora da Ponte ${ }^{27}$.

Porém, nem tudo tinha um contexto aparentemente caótico nessa cidade da virada do século XX. Na belle époque sorocabana havia locais aprazíveis em meio à natureza, por exemplo. 0 anúncio de venda de uma propriedade localizada nos arrabaldes da cidade, demonstrada na Figura 1, é exemplificativo desse fator:

\footnotetext{
22 FAORO, 1993.

23 Jornal Cruzeiro do Sul, 11/01/1905, p.1.

24 MASSARI, 2011.

${ }^{25}$ CELLI, 2012.

26 STRAFORINI, 2001.

27 SILVA, 2007, p.92.
} 
Figura 1 - anúncio de chácara com água encanada em Sorocaba (1912)

\section{Chacara no Rio Acima}

Vende-se a chacra aGuarawirasga com magnifica casa do morada, tondo agua oncauada e exgottos, mais de cem jabuticabeiras em plena produç̧ão, mil e quinhentas laran. jeiras, quatro mil marmeleiros noves, graude porção de café, bom pasto fechado com arame, duas nascentes de boa agua, dazentos pés do kvi, grando bannat, ameixeiras, e muitas fructus diversas. As terras são muiti altas, pois é onde se acha situata a caixa d'zgua do Cubatio. harendo bons mo. ruchos para planta de cereaes. Pura tritir o a o peoprio tario captáo Nats imento em Vutorintim.

Fonte: (Reprodução) Jornal Cruzeiro do Sul, 28/12/1912, p.3

Sorocaba e a divisão do perímetro urbano em zonas: lei Municipal N.119 de 1914

Com relação ao contexto político da municipalidade no início da década de 1910, circulou, em 17 de Janeiro de 1914, a seguinte notícia pela cidade: Dr Luiz Pereira de Campos Vergueiro, líder do Partido Republicano em Sorocaba, foi eleito para presidência da Câmara Municipal28 (Figura 2).

Campos Vergueiro e Augusto César do Nascimento Filho, representantes do legislativo e executivo da municipalidade sorocabana, respectivamente; ambos, presenciaram e participaram

28 Jornal Cruzeiro do Sul, 17/01/1914, p. 1. 
da criação de uma normatização urbana de destaque aos padrões nacionais, em um período que é trabalhado pela historiografia contemporânea como um momento pacificador de ânimos dissidentes ${ }^{29}$.

Figura 2 - Eleição do Presidente da Câmara Municipal de Sorocaba em 1914

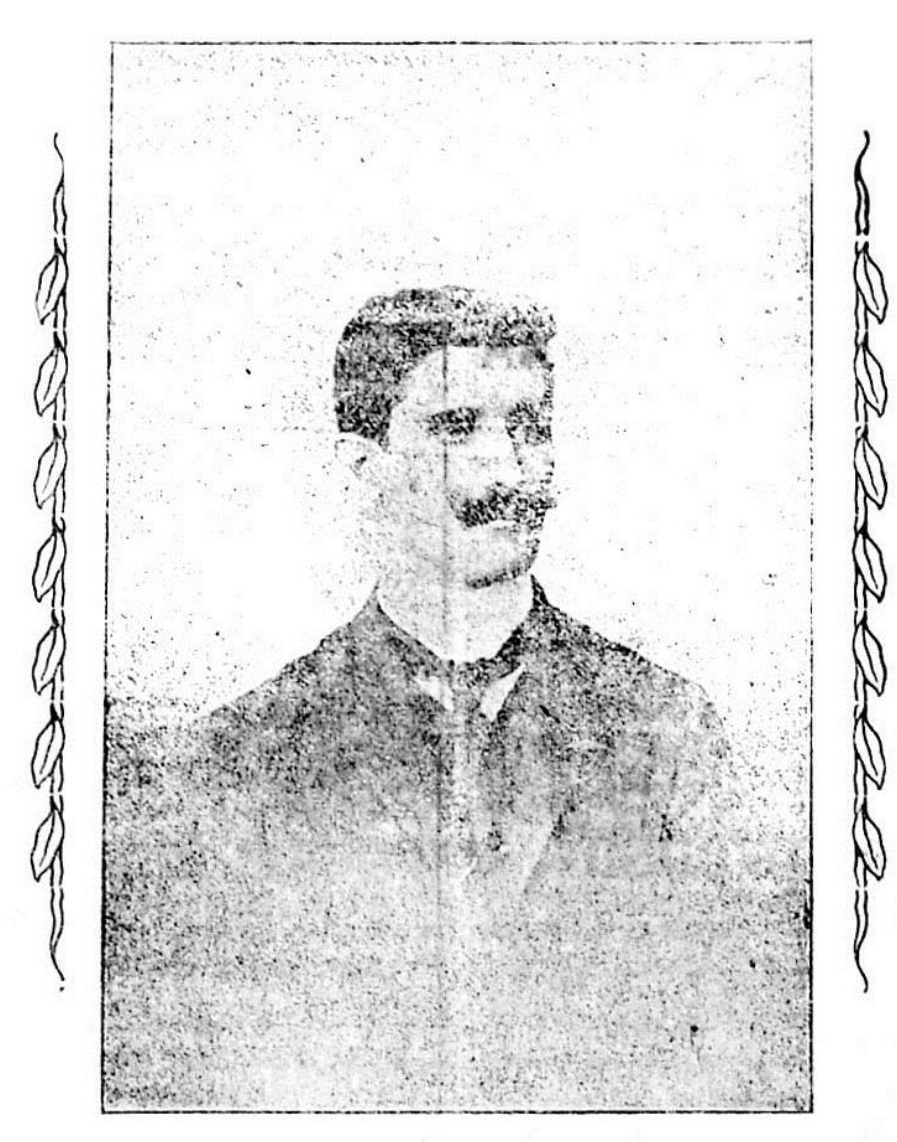

\section{DR. LUIZ PEREIRA DE GAMPOS VERGUEIRO \\ chefe do Partido Republicano de Sorocaba e representante do 4.0 districto no Congresso do Estado, que elegeu a malorla dos vereadoros á nossa Camara Municipal, para cuja presiden- cla fol elelto ante-hontem.}

Fonte: (Reprodução) Jornal Cruzeiro do Sul, 17/01/1914, p. 1.

Com a consolidação de projetos legislativos liberais, encabeçados pelo Partido Republicano local $^{30}$, a cidade pôde ser dividida territorialmente. Esse fenômeno foi condicionado pela lei n. 119 de $1914^{31}$ (Figuras 3, 4 e 5). Na chamada da lei referida estava claro que se tratava da criação de

\footnotetext{
${ }^{29}$ CARVALHO, 2006.

${ }^{30}$ Codificação das Leis da Camara Municipal de Sorocaba (1914-1915). Sorocaba: Typographia Quinze de Novembro, 1915.

${ }^{31}$ Ibidem, p.126-8.
} 
um mecanismo que facilitasse a cobrança de impostos sobre viação, cuja consistência se dava em taxar muros, terrenos cercados e terrenos em aberto, já previsto pela Constituição do Estado de São Paulo (1891). Essa divisão territorial carrega, em si, duas questões relevantes, motivadoras deste trabalho. Em primeiro lugar, por utilizar uma terminologia aparentemente nova para a legislação urbana, sob um contexto nacional: zona ${ }^{32}$. Em segundo lugar, por permitir perceber uma dinâmica complexa da distribuição de certos recursos públicos: água encanada, esgoto e iluminação. É destacável observar, mediante o art. 1o da lei n.119/1914, a definição do zoneamento urbano sorocabano, delimitando-se o que era a cidade, e, por consequência: o que não era (Figura 3).

Figura 3 - Divisão do perímetro urbano de Sorocaba em zonas (lei n.119/14)

\section{LEI N. 119}

Devide 0 perimetro urbano em duas zonas e estabelece nova tabella para 0 imposto de viação sobre muros, terrenos cercados a terrenos em aberto

Art. $1^{\circ}$-Para os effeitos da collecta e cobrança do imposto de viação sobre frentes de muros, terrenos cercados e terrenos em aberto, a que se refere a Lei $n^{\circ} 110$ de 13 de Outubro de 1914, fica perimetro urbano da cidade dividido nas duas seguintes zonas: 1a Zona, delimitada pela rua dr. Alvaro Soares, largo de Santo Antonio, Padre Luiz, Penha, Ipiranga, Cesario Motta até o largo do Jardim, rua dr. Arthur Martins, largo de São Bento, ruas de São Bento, Ponte e Rosario, até a esquina da rua dr. Al. varo Soares, ponto de partida: $2^{\mathrm{a}}$ Zona, abrangenda todu a parte do perimetro urbano situada fóra da parte acima delimitada.

Art. $2^{\circ}$-Dentro da primeira zona o imposto de viaçâı sobre muros, terrenos cercados e terrenos em aberto será cobrado pela seguinte tabella :

Metro de frente de muros de tijolos em ruas calçadas a paralellepipedos, Idem metros em ruas calçadas com pedras não faceadas ou a macadam $2 \$ 500$

32 BORGES, 2007. 
Figura 4: Divisão do perímetro urbano de Sorocaba em zonas (lei n.119/14)

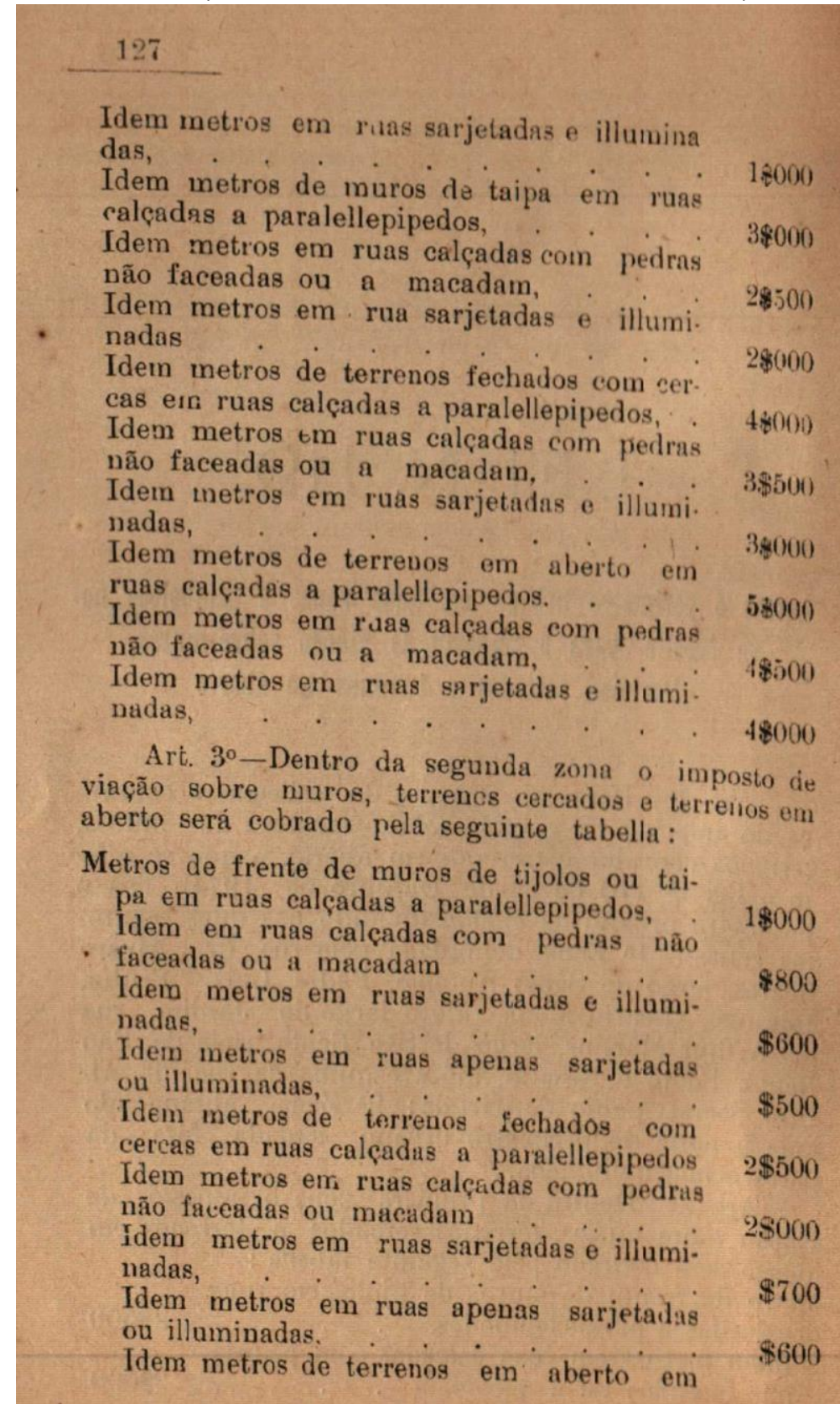

Fonte: Codificação das Leis da Camara Municipal de Sorocaba (1914-1915), p.127. 
Figura 5: Divisão do perímetro urbano de Sorocaba (lei n.119/14)

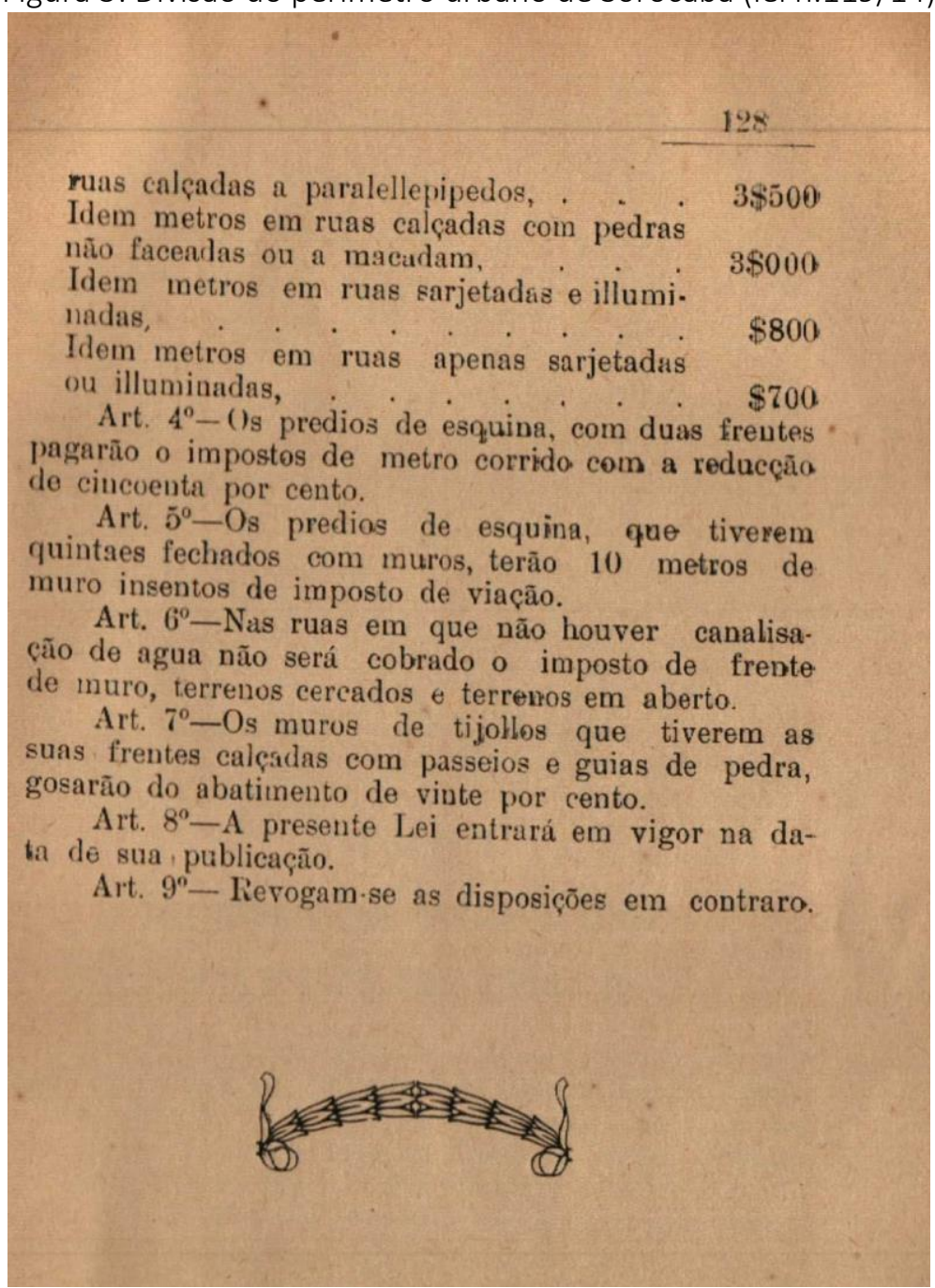

Fonte: Codificação das Leis da Camara Municipal de Sorocaba (1914-1915), p.128.

Outra legislação significativa - à mensuração da dimensão das regiões endógenas e exógenas do perímetro urbano sorocabano a partir de 1914 - é a lei n. 115/1914 ${ }^{33}$, que normatizava acerca do Imposto Predial Rustico; das edificações pertencentes à "zona invisível". Invisível por não ser considerada parte integrante do espaço urbano: "Art. 2o - O imposto predial rustico recahirá sobre todo edificio destinado á habitação situado fóra do perimetro urbano ${ }^{34 \prime}$.

Essa característica social permite assimilação com um estudo de Norbert Elias e John Scotson $(2000)^{35}$, relacionando dissidências de comportamento entre grupos de uma mesma

\footnotetext{
${ }^{33}$ Codificação das Leis da Camara Municipal de Sorocaba (1914-1915). Sorocaba: Typographia Quinze de Novembro, 1915, p. 124

34 Ibidem.

${ }^{35}$ ELIAS, N; SCOTSON, J., 2000.
} 
comunidade. No caso da obra, a análise está centralizada em como os grupos se conheciam e reconheciam, estabelecendo-se noções de superioridade e inferioridade; relacionadas, respectivamente, à tradicionalidade temporal de fixação do assentamento habitacional dos grupos, em uma pequena cidade inglesa de meados do século XX. Em Sorocaba, para o início do século, as relações sociais entre os estabelecidos e outsiders, na análise deste trabalho, não foram observadas pelo recorte acerca do tempo de fixação no local - mesmo sendo considerável salientar que famílias tradicionais geralmente habitassem a primeira e segunda zonas; imigrantes ${ }^{36}$ e pessoas mais pobres: a "zona invisível" - e sim pelo que encarregou, à vivência social, esse zoneamento. Em dialética indutiva e dedutiva, promovida pelas análises das fontes, a abordagem consistiu em observar que aos estabelecidos havia a disponibilidade de recursos de melhoramentos urbanos fundamentais à segurança social, tendo em vista a integridade humana e a salubridade pública (água, esgoto e iluminação pública), mas, em contrapartida, nos locais nãourbanos - nos bairros e regiões outsiders - essa distribuição não era efetiva.

Essas informações levantadas foram possíveis mediante a investigação realizada nos livros da Câmara Municipal de Sorocaba do período. Em um deles foi encontrada uma relação de quais eram as localidades que não pertenciam ao espaço urbano; discriminadas no índice do imposto predial rústico de $1916^{37}$, demonstrado pela Figura 6.

\footnotetext{
${ }^{36}$ COELHO, 2002.

${ }^{37}$ Camara Municipal de Sorocaba - Lançamento do Imposto Predial Rustico - Ano 1916 - Livro 438.
} 
Figura 6 - Índice do Livro da Câmara para o Imposto Predial Rústico de Sorocaba em 1916

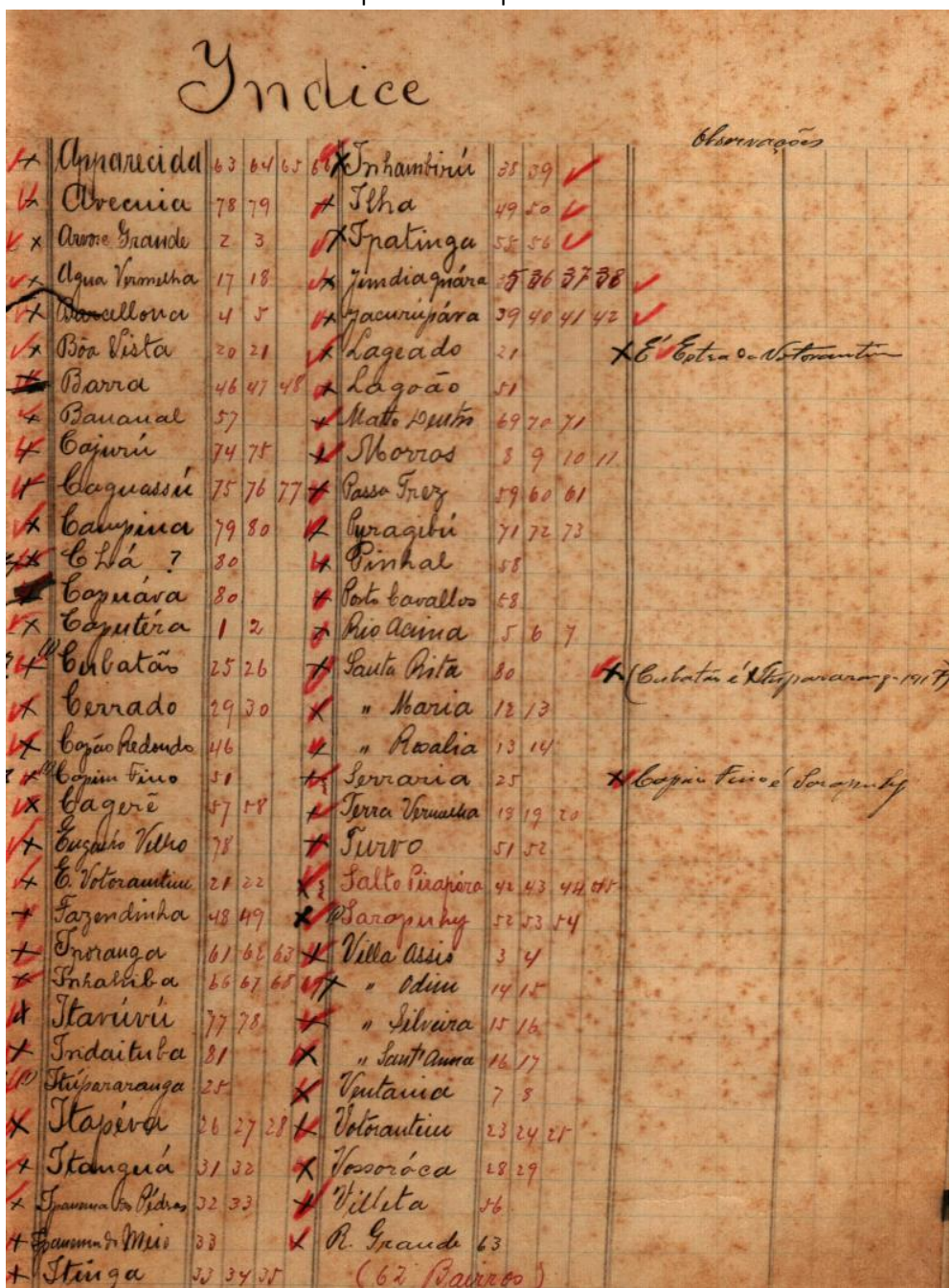

Fonte: Museu Histórico Sorocabano - Índice do Lançamento do Imposto Predial Rustico , Ano 1916 - Livro 438

Impostos sorocabanos: 1916

As informações da coleta de impostos sorocabanos, que serão analisadas e apresentadas na sequência da narrativa deste trabalho, foram retiradas dos Livros da Câmara Municipal de 1916. Respectivamente, utilizou-se: Lançamento do Imposto Predial Rustico (Livro 438), Lançamento do Imposto Predial Urbano (Livro 436) e Lançamento do Imposto de Viação (Livro 439). Conforme as Figuras 7 (imposto urbano) e 8 (imposto rústico) é possível dimensionar melhor os dispositivos das 
leis n. 110 (Figuras 9, 10, 11 e 12), 115 (Figuras 13 e 14) e 119 (Figuras 3.4 e 5) - ambas de 1914 - relativos a uma amostragem de contribuintes e valores correspondentes.

Figura 7 - Contribuintes e Impostos Urbanos

\begin{tabular}{|c|c|c|c|c|c|c|c|c|c|}
\hline CONTRIBUINTE & $\begin{array}{l}\text { SITUACCÃO } \\
\text { DOŚ } \\
\text { PRÉDIOS }\end{array}$ & $\mathrm{N}^{0}$. & $\begin{array}{l}\text { VALOR } \\
\text { LOCATIVO } \\
\text { DOS } \\
\text { PRÉDIOS }\end{array}$ & $\begin{array}{c}\text { IMPORTÂNCIA } \\
\text { DO } \\
\text { IMPOSTO } \\
\text { PREDIAL } \\
\text { URBANO } \\
\text { EM 1916 } \\
\text { (Livro 436) }\end{array}$ & $\begin{array}{l}\mathrm{F} \\
\mathrm{O} \\
\mathrm{L} \\
\mathrm{H} \\
\mathrm{A}\end{array}$ & $\begin{array}{l}\text { IMPORT ÄNCIA DO } \\
\text { IMPOSTO DE } \\
\text { VIACCÃO EM 1916 } \\
\text { (Livro 439) }\end{array}$ & $\begin{array}{c}\text { QUANTIDADE } \\
\text { DE } \\
\text { METROS }\end{array}$ & POR METRO & $\begin{array}{l}\mathrm{F} \\
\mathrm{O} \\
\mathrm{L} \\
\mathrm{H} \\
\mathrm{A}\end{array}$ \\
\hline \multirow{2}{*}{ Anna Candida G. } & $\begin{array}{c}1^{2} \text { zona / R. } \\
\text { Alvaro Soares }\end{array}$ & 35 & 960.000 & 57.600 & \multirow{2}{*}{10} & \multirow{2}{*}{4.500} & \multirow{2}{*}{15} & \multirow{2}{*}{300} & \multirow{2}{*}{7} \\
\hline & $\begin{array}{c}1^{2} \text { zona/ } R \text {. } \\
\text { Alvaro Soares }\end{array}$ & 37 & 420.000 & 25.200 & & & & & \\
\hline Antonio Miguel Candozo & $\begin{array}{l}1^{2} z o n a / R . \\
\text { Padre Luiz }\end{array}$ & 14 & 360.000 & 21.600 & 8 & 3.300 & 11 & 300 & 4 \\
\hline Alvaro Soares & $\begin{array}{c}1^{2} \text { zona / R. da } \\
\text { Penha }\end{array}$ & 16 & 960.000 & 57.600 & 3 & 3.900 & 13 & 300 & 2 \\
\hline $\begin{array}{c}\text { Delphino Epiphanio } \\
\text { Oliveira }\end{array}$ & $\begin{array}{c}1^{2} \text { zona/R. } \\
\text { Cesario Motta }\end{array}$ & 4 & 600.000 & 36.000 & 21 & 4.300 & 16 & 300 & 15 \\
\hline Elvira Pires & 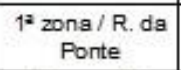 & 21 & 720.000 & 43.200 & 24 & 3.300 & 11 & 300 & 17 \\
\hline Alexandrina Maria Dias & $\begin{array}{c}2^{2} \text { zona / R. } \\
\text { Cel. } \\
\text { Caval heiros }\end{array}$ & $\begin{array}{l}15 \\
17\end{array}$ & $\begin{array}{l}240.000 \\
420.000\end{array}$ & $\begin{array}{l}14.400 \\
25.200\end{array}$ & 7 & 9.300 & 31 & 300 & 2 \\
\hline Issac Pacheco & Votorantim & $25 / 27$ & 480.000 & 28.800 & 35 & 2.200 & 11 & 200 & 26 \\
\hline Josquina dos Sentos & 7 Setembro & 25 & 360.000 & 21.600 & 39 & 3.300 & 11 & 300 & 27 \\
\hline Lucrecia Loureiro Arruda & $\begin{array}{l}\text { Largo de Säo } \\
\text { Bento }\end{array}$ & 9 & 300.000 & 18.000 & 51 & 1800 & 6 & 300 & 41 \\
\hline \multirow[t]{2}{*}{ Pareirs lgnacio \& Comp. } & \multirow{2}{*}{$\begin{array}{l}1^{2}=20 n s / R \text {. } \\
\text { Alvaro Sogres }\end{array}$} & 46 & 1200.000 & 72.000 & \multirow{2}{*}{61} & \multirow{2}{*}{68.700} & 37 & 600 & \multirow{2}{*}{50} \\
\hline & & 48 & 3.000 .000 & 180.000 & & & 155 & 300 & \\
\hline
\end{tabular}

Fonte: Museu Histórico Sorocabano - Livros da Câmara

38 Codificação das Leis da Camara Municipal de Sorocaba (1914-1915). Sorocaba: Typographia Quinze de Novembro, 1915, p.107-110; 124-125; 126-128. 
Figura 8 - Contribuintes e Impostos Rústicos

\begin{tabular}{|c|c|c|c|c|c|c|c|c|}
\hline CONTRIBUINTE & $\begin{array}{c}\text { SITUAÇÄO } \\
\text { DOS } \\
\text { PRÉDIOS }\end{array}$ & $\begin{array}{c}\text { AREA } \\
\text { EM } \\
\text { METROS }\end{array}$ & $\begin{array}{c}\text { IMPOSTO } \\
\text { PREDIAL } \\
\text { RÚSTICO } \\
\text { LIQQUIDO EM } \\
1916 \\
\text { (Livro 438) }\end{array}$ & $\begin{array}{l}F \\
O \\
L \\
H \\
A\end{array}$ & $\begin{array}{c}\text { IMPOSSTO DE } \\
\text { VIAÇÄO EM } \\
1916 \\
\text { (Livro 439) }\end{array}$ & $\begin{array}{c}\text { QUANTIDADE } \\
\text { DE } \\
\text { METROS }\end{array}$ & $\begin{array}{l}\text { POR } \\
\text { METRO }\end{array}$ & $\begin{array}{l}\mathrm{F} \\
\mathrm{O} \\
\mathrm{L} \\
\mathrm{H} \\
\mathrm{A}\end{array}$ \\
\hline João Rodrigues Dias & Barcellona & 28 & 2.500 & 5 & Não encontrado & & & \\
\hline Santhiago Sanches & Barcellona & 24 & 2.500 & 5 & Não encontrado & & & \\
\hline $\begin{array}{l}\text { Antônio José } \\
\text { Florencio }\end{array}$ & Morros & 16 & 1.500 & 11 & Não encontrado & & & \\
\hline Marcelino José Pedro & Morros & 25 & 2.500 & 11 & Não encontrado & & & \\
\hline Antonio Simão Leme & Santa Rosalia & 63 & 7.000 & 13 & Não encontrado & & & \\
\hline Benedicto Joaquim & Santa Rosalia & 30 & 2.500 & 13 & Não encontrado & & & \\
\hline $\begin{array}{l}\text { Augusto Cesar do } \\
\text { Nascimento Filho }\end{array}$ & Rio Acima & $48 / 70$ & $7.000 \mathrm{cada}$ & 6 & S. Cruz, n. .57 & 18 & 300 & 9 \\
\hline Raymmundo Prestes & Rio Acima & 30 & 2.500 & 6 & Não encontrado & & & \\
\hline Celina Neves & Cerrado & 100 & 12.000 & 29 & Não encontrado & & & \\
\hline Amna Moreira & Cerrado & 26 & 1.500 & 30 & Não encontrado & & & \\
\hline Pedro Teixeira Seabra & Vossoróca & 15 & 1.500 & 28 & Não encontrado & & & \\
\hline $\begin{array}{l}\text { Ovidio Laurentino do } \\
\text { Amaral }\end{array}$ & Vossoróca & 120 & 12.000 & 29 & Não encontrado & & & \\
\hline
\end{tabular}

Fonte: Museu Histórico Sorocabano - Livros da Câmara

Analisando-se os dados dos contribuintes, é possível perceber a discrepância de valores por regiões da cidade. Do maior valor apresentado pela Figura 7, referente ao industrialista Pereira Ignacio \& Comp (R. Álvaro Soares - 1a zona), à maior quantia apresentada pela Figura 8, referente a Celina Neves (Cerrado - rústico), têm-se a diferença aproximada de vinte uma vezes a importância do imposto pago. Comparando-se a edificação de menor tributo na Figura 7, referente a Alexandrina Maria Dias (R. Coronel Cavalheiros - 2a zona), com o de menor valor da Figura 8, referente a Antônio José Florencio, Anna Moreira e Pedro Teixeira (Morros, Cerrado e Vossoróca rústico), a diferença é de aproximadamente 9 vezes a quantia.

Mas, em que consiste essa diferenciação no valor dos impostos, quanto à materialidade dos recursos nas distintas localizações? É possível encontrar pistas na distribuição dos melhoramentos urbanos: água encanada, esgoto e iluminação pública.

Para compreender essa característica é importante entender uma peculiaridade do imposto de viação. Eram isentos hospitais, igrejas, centros de educação primária gratuita, associações de ensino de língua estrangeira e, conforme o inciso 60 do art.153: “6 - Os terrenos 
em aberto ou cercados a arame liso, situados nos bairros que não tiverem serviços de illuminação e agua e exgottos ${ }^{39 \prime \prime}$.

Figura 9 - Imposto de Viação (lei n. 110/14)

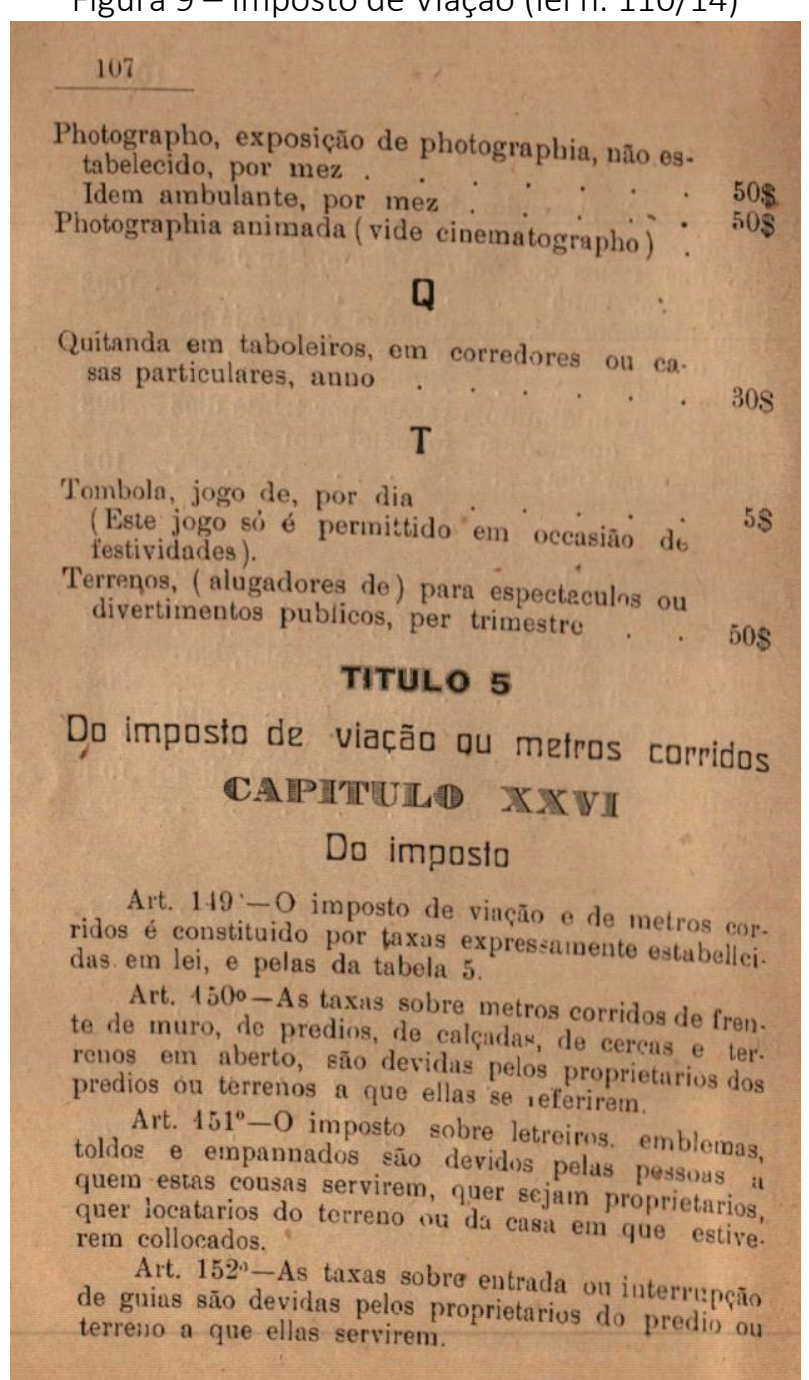

Fonte: (Reprodução) Codificação das Leis da Camara Municipal de Sorocaba (1914-1915), p.107.

39 Ibidem, p.108. 
Figura 10 - Imposto de Viação (lei n.110/14)

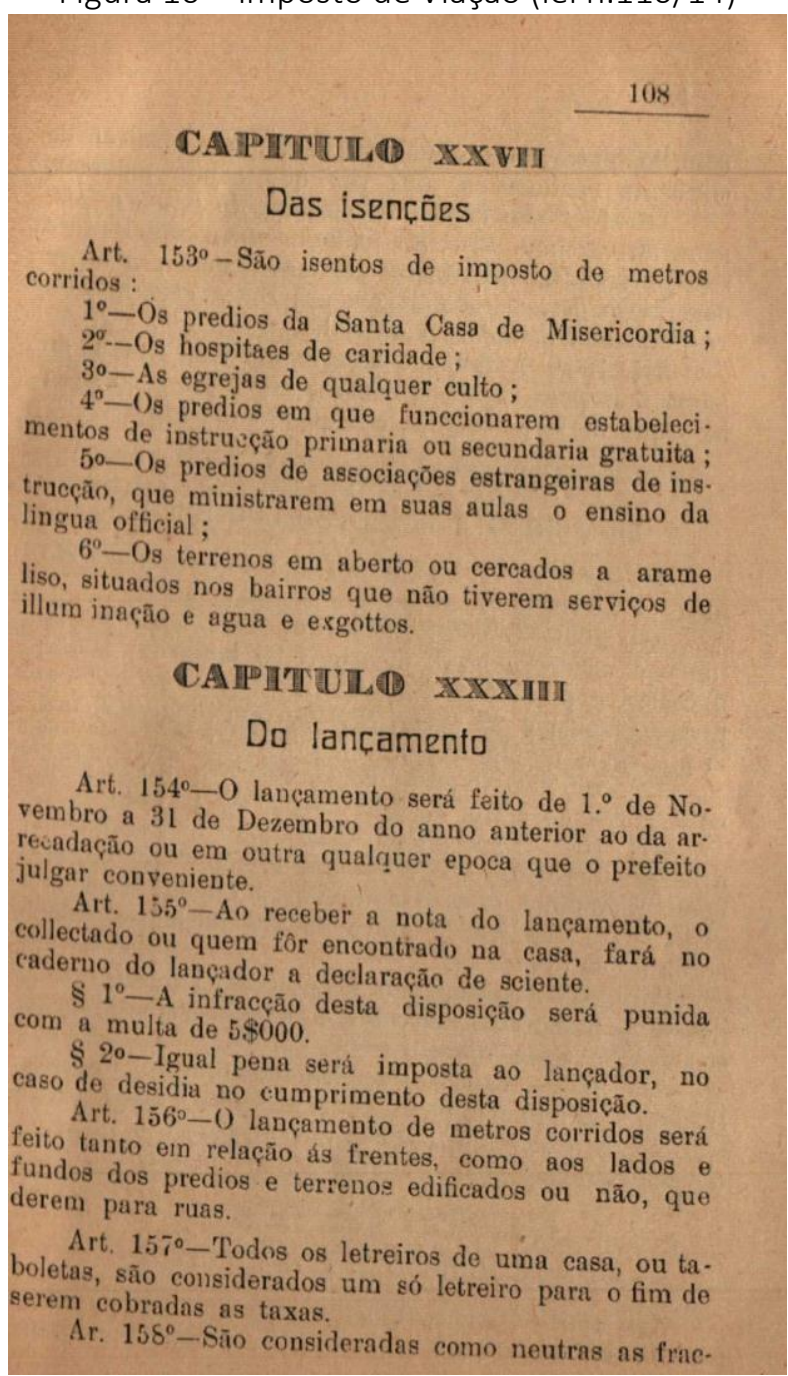

Fonte: (Reprodução) Codificação das Leis da Camara Municipal de Sorocaba (1914-1915), p.108. 
Figura 11 - Imposto de Viação

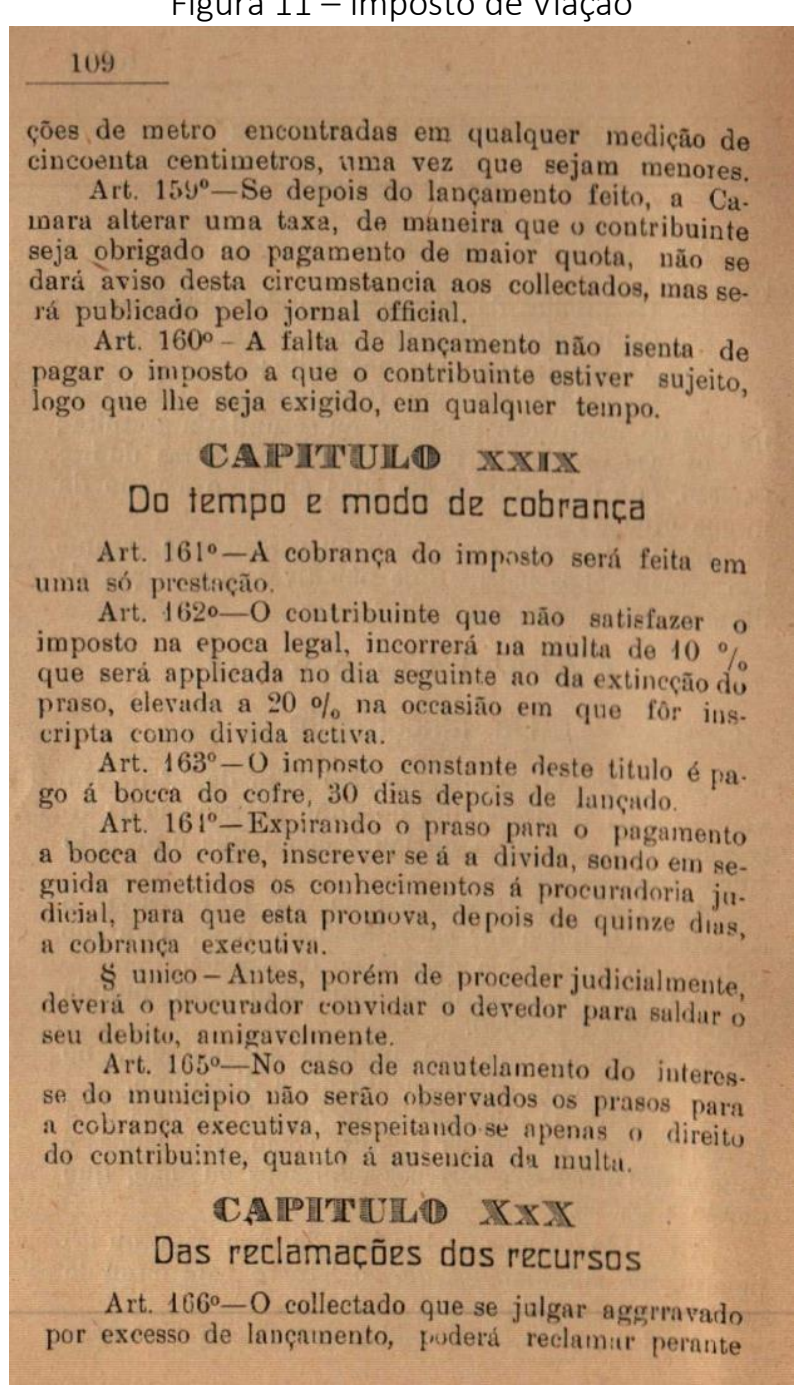

Fonte: (Reprodução) Codificação das Leis da Camara Municipal de Sorocaba (1914-1915), p.109. 
Figura 12 - Imposto de Viação

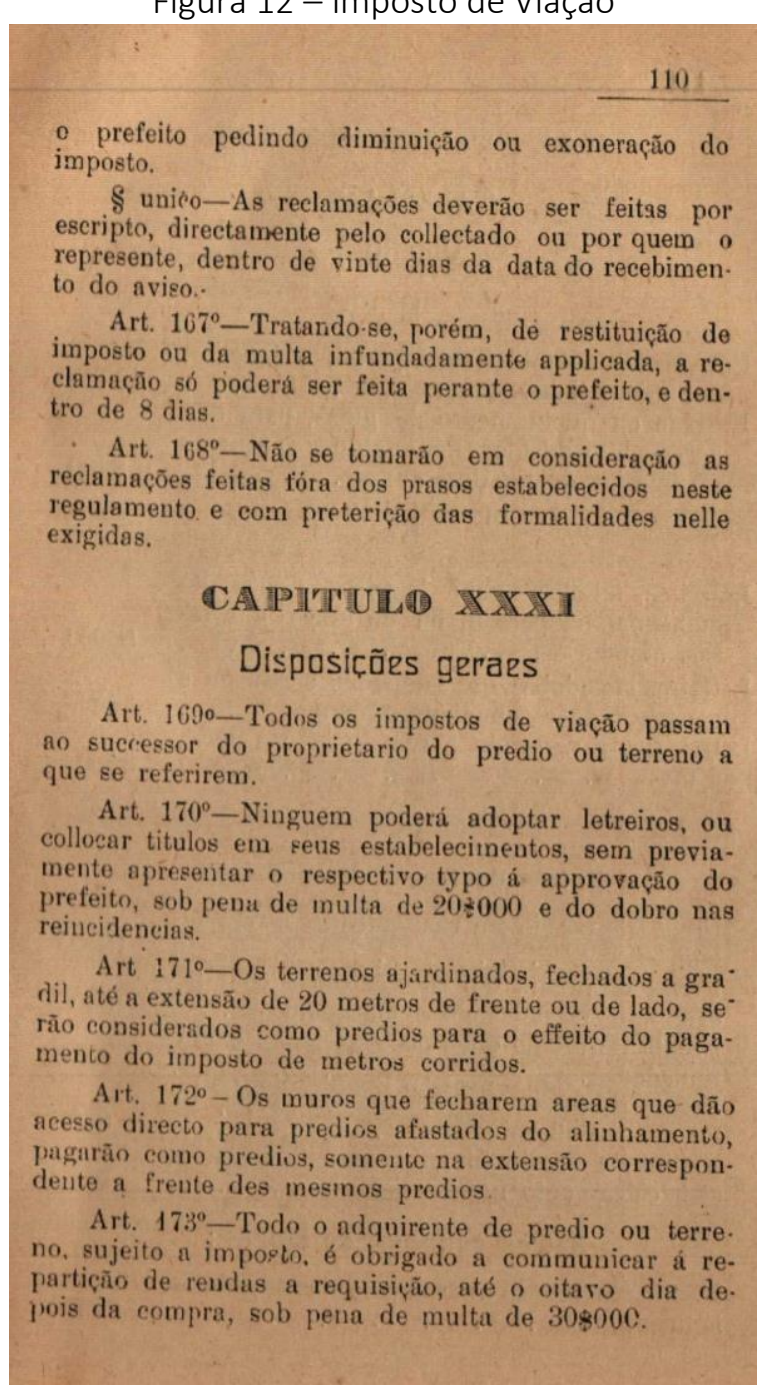

Fonte: (Reprodução) Codificação das Leis da Camara Municipal de Sorocaba (1914-1915), p.110.

Observando-se os lançamentos de impostos da Câmara de Sorocaba em 1916, foi possível identificar que o Prefeito - Augusto César do Nascimento Filho - conhecido como Capitão Nascimento ${ }^{40}$, deveria pagar impostos prediais referentes a três propriedades: duas estavam

40 "O Capitão Augusto César do Nascimento Filho nasceu em 10 de julho de 1880, na cidade de Campinas. Filho do Coronel Augusto César do Nascimento e de dona Adelaide Roso do Nascimento, membros de uma tradicional família campineira. Fez seus estudos no Colégio Culto às Ciências, de Campinas, formando-se 'Contador' (...) foi em 1911, convidado pelo Comendador Pereira Ignácio, para dirigir a Fábrica Votorantim. Pelo seu reconhecido tirocínio gerencial, nesse mesmo ano, em 1914, foi eleito Prefeito de Sorocaba, cargo no qual esteve até 1921. Como Prefeito revelou-se um urbanista de grandes méritos (...) Um fato marcante ocorreu no primeiro mandato do Capitão Nascimento (1914/1921) (...) O Prefeito baixou um decreto proibindo a entrada de carros-de-boi pela zona central da cidade (...) O consagrado Prefeito morreu pobre em 15 de novembro de 1952, com 72 anos de idade"[grifos do autor]. (WEY NETTO, 2015, p.97-8). Veja também em ALMEIDA, 2002, p.364-70. 
situada no Rio Acima (Livro 438 - Predial Rústico ${ }^{41}$ ) e outra foi possível identificar pelo Livro 439, acerca do Imposto de Viação ${ }^{42}$, relativo à propriedade na R. Santa Cruz, localizada na 2a zona; acerca deste patrimônio, não foi encontrado registro de Imposto Predial Urbano em 1916. Além disso, há duas especificidades em uma das propriedades do Rio Acima que merecem destaque. Em primeiro lugar, em consonância com a lei municipal n. 115 de 1914, não haveria necessidade de Augusto César pagar o Imposto Predial Rústico (ao menos na Chácara Guaramiranga; supondo que a venda anunciada no jornal não chegou a se realizar, sendo, àquela, propriedade do Capitão Nascimento), caso ainda existissem as plantações de café, conforme o anunciado em 1912 (ver Figura 1), visto que o art. 3o da lei n. 115/1914 isentava propriedades com o uso cafeeiro. Em segundo lugar, a Chácara, anunciada à venda, tinha água encanada e esgoto, mas não consta o pagamento de Imposto de Viação (1916/1917) desta; essa complexidade não anula a possibilidade, mesmo que remota, de que a água encanada estivesse vinculada às nascentes da propriedade, mas estreita a viabilidade de anulação caso a relação seja a mesma para analisar a questão do esgoto. Talvez, o que esclareça a intencionalidade de expor a relação da localização da propriedade com a caixa d'água do Cubatão - de forma a proporcionar melhor entendimento da distribuição hídrica, ao menos na Chácara Guaramiranga, e instigar outras propostas de pesquisa a desdobrar o assunto - tenha subsídio na seguinte informação: "A cidade é abastecida pelo grande manancial do Cubatão, cuja água foi considerada pelo Laboratorio de Analyses do Estado, como de superior qualidade ${ }^{43 \prime \prime}$, conforme o Almanach de Sorocaba para 1903.

Essa situação é curiosa, pois as localidades rústicas da cidade, ou seja, a "zona invisível" não era abastecida pela rede, ao menos na maioria esmagadora das propriedades verificadas nos livros da Câmara e utilizadas de referência nesta pesquisa, bem como na bibliografia acadêmica que se dedicou ao contexto ${ }^{44}$. A ausência desse recurso importante, concomitante ao esgoto e iluminação, isentava de impostos de viação os terrenos situados nos bairros não atendidos pelas redes distribuidoras. O bairro do Rio Acima (subentendido como bairro rústico) estava situado na região da caixa d'água do Cubatão. Sendo assim, as propriedades nas respectivas imediações podiam não ter o serviço instalado, mas o bairro tinha possibilidades de acesso, ao menos, ao líquido precioso. Dessa forma, surge uma curiosidade: propriedades atendidas pelos referidos recursos - mesmo que parcialmente - deveriam participar da contribuição do imposto de viação?

\footnotetext{
${ }^{41}$ Camara Municipal de Sorocaba - Lançamento do Imposto Predial Rustico - folha 6 - Ano 1916 - Livro 438.

${ }^{42}$ Camara Municipal de Sorocaba - Lançamento do Imposto de Viação - Ano 1916 - folha 9 - Livro 439.

${ }^{43}$ SILVA (org.), 2007, p.90.

${ }^{44}$ CARVALHO, 2008.
} 
No perímetro urbano, o art. 60 da Lei 119/14 isentava da cobrança propriedades em ruas que não tivessem água canalizada. Nas localidades rústicas do município subentende-se que deveria ser aplicado o dispositivo configurado pelo $\S 60$ do art. 153ㅇ da Lei 110/14, no qual determinava que terrenos em bairros com ausência de água encanada, esgotos e iluminação deveriam ser isentos. Sendo assim, observa-se que o bairro do Rio Acima era potencialmente abrangido pela distribuição de água e esgoto, mas não há registros acerca da iluminação. A esse respeito, justifica-se o não registro das propriedades do Rio Acima no Livro 439 (Imposto de Viação para 1916).

Acerca da iluminação, os bairros que não fossem atendidos tinham como impedimento a própria fornecedora. Em um importante documento, digitalizado pelo Museu Histórico Sorocabano, foi possível perceber a articulação da companhia na disposição das áreas que receberiam eletricidade. Cabe informar que não há especificação para a datação do documento; acredita-se que este seja contemporâneo às cobranças de impostos referidos neste trabalho; valendo-se da referência monetária, sabe-se que é anterior aos anos 1940. No ítem 1 - das Regras e Regulamentos para o fornecimento de energia elétrica da The São Paulo Electric Company, Ltd (Figura 15) - ficava claro que a empresa teria o direito de recusar pedidos de instalação, por considerar inviável. Esses termos, subtendidos enquanto contratuais, provavelmente tiveram o aval da municipalidade sorocabana contemporânea ao estabelecimento da empreitada da companhia no início da década de 1910. O dispositivo mencionado do ítem 1 pode ter funcionado, mesmo que de maneira involuntária, como minimizador do potencial de desenvolvimento de diversas localidades no município, ao menos sob a perspectiva da industrialização de centros comerciais. Dessa forma, há mais facilidade na ocorrência de especulação imobiliária em áreas já infraestruturadas.

Figura 13 - Imposto Predial Rústico (lei n.115/1914) 


\section{LEI N. 115}

\section{Imposto predial Rustico}

Art. 1" - Fica creado neste municipio o impos. to predial rustico, com especial consignação aos servięos de abertura $\theta$ conservação de estradas munici. paes, nos termos da Lei $n^{\circ} 1439$ de 19 de Dezembro de 1914.

Art. $2^{\circ}-\mathrm{O}$ imposto predial rustico recahirá sobre todo edificio destiuado á Labitação situado fóra do perimetro urbano

$\$ 10$-O lançamento do imposto, a que se procederá no mez de abril de cada anno, será feitu na base da area construida e de accordo com a tabella annexa.

\$. $2^{\circ}-\mathrm{A}$ arrecadação dó imposto será feita no mez de Julho de cada anno.

\$3 -O processo do lançanmento e os recursos que delle couberem serão os mesmos admittidos para $\checkmark$ imposto predia!

Art 3o-Ficain isentos deste imposto tocios os predios das propriedades cafeeiras.

Fonte: (Reprodução) Codificação das Leis da Camara Municipal de Sorocaba (1914-1915), p.124. 
Figura 14 - Imposto Predial Rústico (lei n. 115/1914)

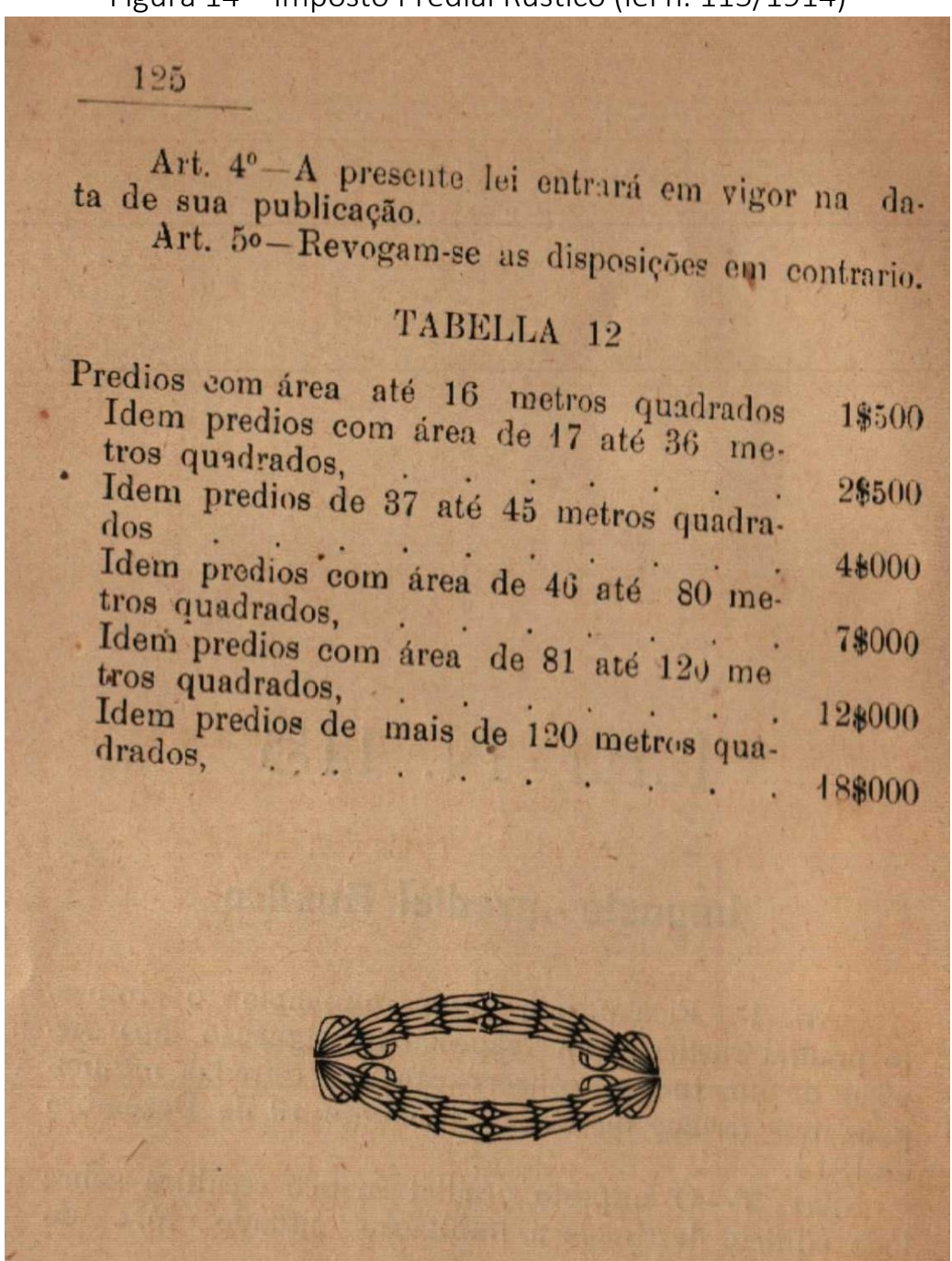

Fonte: (Reprodução ) Codificação das Leis da Camara Municipal de Sorocaba (1914-1915), p.125. 
[Figura 15 - Regras e regulamentos para o fornecimento de energia elétrica

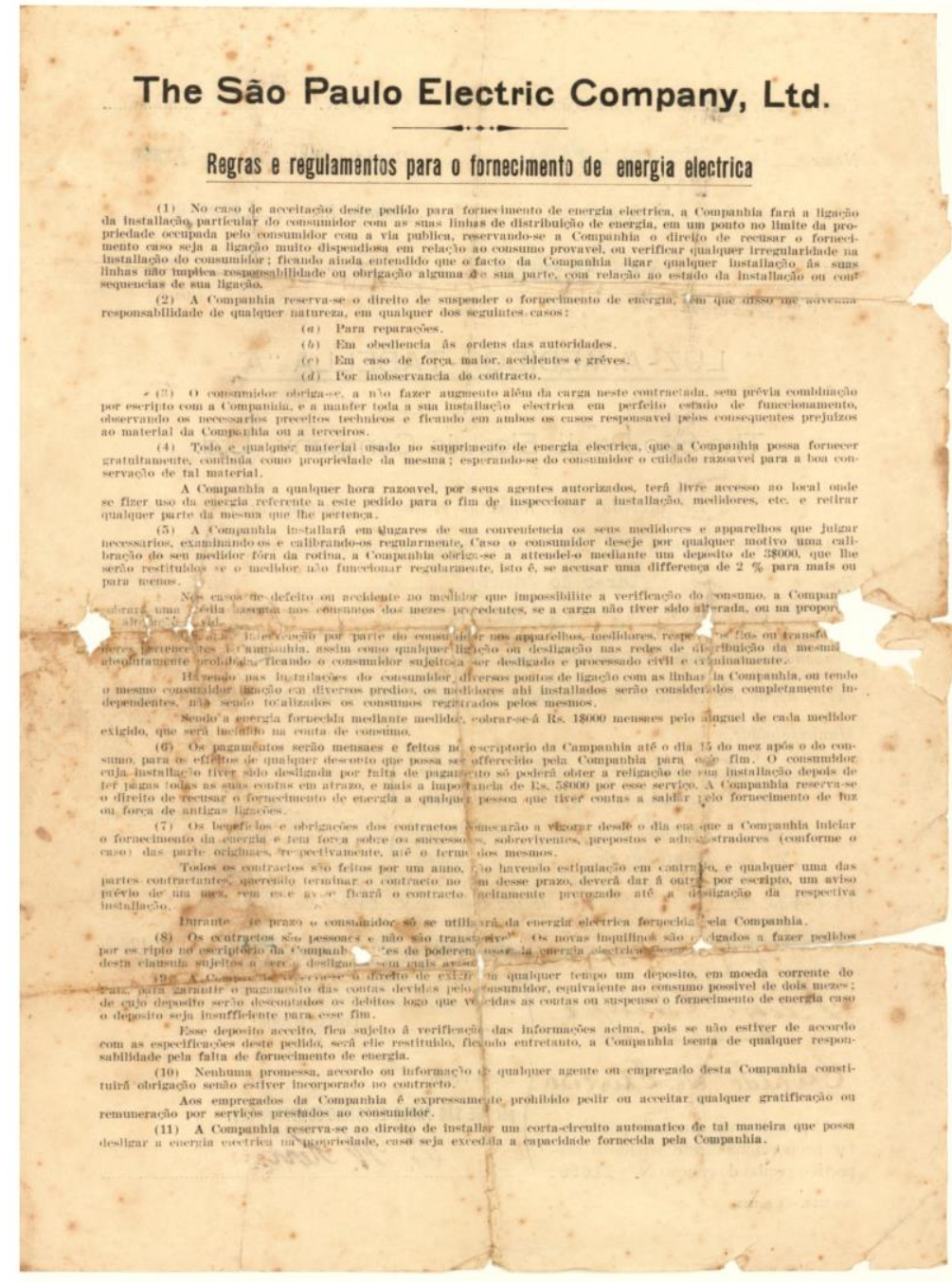

Fonte: Museu Histórico Sorocabano - Arquivo Digital P8-059] [inseri]

\section{ENTRE A TEORIA E A PRÁTICA}

Ampliando-se a questão, acerca do comportamento das classes dominantes, sob o ponto de vista da aliança entre ideologia e práticas sociais, recorreu-se à obra da historiadora e antropóloga Lilia Schwarcz (2007), que dedicou atenção à conjuntura do cientificismo brasileiro da virada do século XX. Dessa forma, ilustra-se uma particularidade do universo cognitivo acessível aos administradores públicos municipais brasileiros do período em análise: o que aqui se consome são modelos evolucionistas e social-darwinistas, originalmente popularizados enquanto justificativas teóricas de práticas imperialistas de dominação ${ }^{45}$. Um importante teórico do Direito social-

${ }^{45}$ SCHWARCZ, 2007, p.30. 
darwinista, com relação à influência aos republicanos históricos ligados às correntes liberais brasileiras ${ }^{46}$, principalmente paulistas, é Herbert Spencer $(1891)^{47}$.

A crítica à perspectiva darwinista social, bem como a evolucionista - cujo caráter consistia na diferenciação por raça, classe econômica e outras equacionadas em tipificações de superioridade e inferioridade - está alicerçada em três concepções multidimensionais, na perspectiva deste trabalho; em uma escala interdisciplinar: uma está vinculada à teoria da História Cultural, outra na teoria e metodologia em História da Arquitetura e Urbanismo e, por fim, em Filosofia. Ambas, atenciosas à inteligibilidade e relacionamento do poder para com os discursos e a realização prática, além de pertencerem às comunidades que subsidiaram, ideologicamente, o Brasil da República Velha, de forma a explanar a crítica pelas nações que originaram a tendência que outrora aqui fora consumida com maior frequência.

De acordo com a abstração do historiador cultural francês Roger Chartier (2010), há uma importante advertência às práticas de observação historiográfica, ou àquelas que se apreendem ao passado: "Daí se depreende o principal desafio que se apresenta à história cultural: como pensar a articulação entre os discursos e as práticas ${ }^{48 \prime}$. Ideia reforçada pela narrativa teórico-metodológica em obra epistemológica de Linda Groat e David Wang (2013), com relação à estruturação do pensamento vinculado à metodologia da história da arquitetura e urbanismo, sob um viés epistêmico pós-estruturalista:

Poststructuralism rejects transcendentally constant bases for meaning. Instead, it holds that "reality" is a by-product of "discourse," and hence subservient to it. For Michel Foucault, for instance, historical periods come and go, each period understood as a web of discourses, only to be replaced by another period, understood as another web of discourses. This rejects a universal or transcultural understanding of "reality," in which certain ideational benchmarks remain constant (e.g., "progress," "heaven," "nature," "man," and so on). Hence Lyotard's "incredulity toward metanarratives" noted earlier $)^{49}$.

E com Michel Foucalt (1979), intercalando-se as perspectivas subsidiárias à criticidade que aqui se constrói, acerca do período objeto, é possível compreender as estruturas da força do poder; quais os mecanismos mais íntimos das relações que o legitimam, fortalecem. No caso, o filósofo afirma que:

\footnotetext{
${ }^{46}$ CARVALHO, 1987, p.24

47 SPENCER, 1891.

${ }^{48}$ CHARTIER, 2010, p.47.

${ }^{49}$ GROAT, L. ; WANG, D., 2013, p. 192-3
} 
Quando se define os efeitos do poder pela repressão, tem-se uma concepção puramente jurídica deste mesmo poder; identifica-se o poder a uma lei que diz não. O fundamental seria a força da proibição. Ora, creio ser esta uma noção negativa, estreita e esquelética do poder que curiosamente todo mundo aceitou. Se o poder fosse somente repressivo, se não fizesse outra coisa a não ser dizer não você acredita que seria obedecido? O que faz com que o poder se mantenha e que seja aceito é simplesmente que ele não pesa só como uma força que diz não, mas que de fato ele permeia, produz coisas, induz ao prazer, forma saber, produz discurso. ${ }^{50}$

A evidência da eficiência metodológica da análise pós-estruturalista para pormenorizar a questão envolvida, acerca da distribuição dos melhoramentos urbanos referidos em Sorocaba do início do século XX, é reforçada pela abordagem do conteúdo da tese defendida por Rogério de Carvalho (2008), em História Social pela Universidade de São Paulo. Em resgate ao discurso midiático sorocabano do período é possível evidenciar a justificativa da escolha metodológica de abordagem crítica das fontes primárias e secundárias utilizadas neste trabalho:

Sorocaba, sendo hoje uma cidade perfeitamente saneada, com admirável rede de água e exgottos, optima illuminação electrica, possuindo magnífica linha de telephones e de telegrapho nacional, com linha de automóveis, fasendos-e approximar deste modo aos municípios que the são adjacentes, gozando de um clima magnífico, distando apenas três e meia horas da Capital, e muito chegada ao Ipanema, - onde se encontra talvez a mais rica minha de ferro do mundo, Sorocaba offerece por tudo isso, aos srs. Capitalistas que desejam bem empregar os seus capitais os seus recursos monetários em novas e desconhecidas industrias, campo vasto de exploração, pela facilidade que há em obter-se força motriz e ainda mais que aqui se encontram operários habilitados para qualquer ramo de industria. ${ }^{51}$

Essa questão é muito séria e, nas análises dos dados utilizados pelo historiador, há a afirmação de que "Em 1914, a cidade estava muito longe de estar saneada e a rede de água e esgotos, assim como a iluminação elétrica atendia, e mesmo assim de forma precária, uma parte do núcleo urbano da cidade ${ }^{52 " .}$. Esse fato também foi corroborado neste presente trabalho, utilizando-se de outras fontes e formas de análises foi possível identificar e especificar essa explanação de Rogério de Carvalho (2008), além de dimensionar as regiões atendidas por esses recursos, bem como as normatizações municipais que orbitavam esse contexto singular. É importante destacar, acerca do raciocínio da tese do autor, que a questão da má distribuição dos recursos públicos se estendeu por longas datas, posto que:

Para a população que residia no lado oriental da cidade, além do rio Sorocaba, e nos outros arrabaldes que começariam a se expandir nas

\footnotetext{
50 FOUCALT, 1979, p.7-8.

${ }^{51}$ WERNECK, 2006 apud CARVALHO, 2008, p.63.

52 CARVALHO, 2008, p.63.
} 
primeiras décadas do século XX, a questão da água seria um problema premente e não resolvido ao longo de boa parte do século passado. ${ }^{53}$

A região do Rio Acima, por exemplo, circunscrevia-se à porção oriental referida na máxima de Rogério de Carvalho (2008).

Talvez, subsidiado pela construção epistemológica da crítica ao relacionamento duvidoso de certos discursos e práticas, seja possível questionar, no caso da distribuição desses melhoramentos em Sorocaba, qual a efetividade dos princípios de igualdades contidos na Constituição da República (1891) e Constituição do Estado de São Paulo (1891); de certa forma, é tarefa árdua, sendo o léxico necessário para a respectiva condução da observação deveras complexo, necessitando-se, assim, de análises pormenorizadas e com fontes privilegiadas.

\section{BREVE OBSERVAÇÃO DA CRÍTICA ACADÊMICA ACERCA DO ZONEAMENTO NO BRASIL}

Analisando-se a hereditariedade republicana brasileira, José Murilo de Carvalho (1990) busca a essencialidade das referências ideológicas que foram, de certa forma, absorvidas pelos intelectuais brasileiros, indicando-se a nacionalidade das ideias importadas pelo país:

Como país exportador de matérias-primas e importador de ideias e instituições, os modelos de república existentes na Europa e na América, especialmente nos Estados Unidos e na França, serviram de referência constante aos brasileiros ${ }^{54}$.

Cabe salientar que essas ideias, ensaiadas pelas respectivas localidades originárias, carregavam certos sentidos passivos de contrariedades. Dessa forma, é ilustrativo resgatar, ao menos, o que ocorria em Paris; uma cidade de grande profusão de parte desses modelos e ideários.

Analisando os operários, a habitação e a cidade de Paris na virada do século XX, Michelle Perrot (1988) percebe o centro urbano como um elemento fundamental na disputa de poderes: "Nessas circunstâncias, não admire que todo movimento revolucionário seja uma reconquista do centro. Lá estão os imóveis e os símbolos do poder ${ }^{55 " .}$ Esse contexto, relatado pela autora, está relacionado às reorganizações urbanísticas realizadas, principalmente, pelas práticas de Haussman no século XIX, cujos impactos promoveram o esvaziamento das classes mais pobres do centro da cidade. Estas, circunscritas ao movimento operário, reivindicavam baixa nos preços dos aluguéis das áreas centrais, bem como a permissividade na aglomeração habitacional, de forma com que

\footnotetext{
53 Ibidem, p.109.

${ }^{54}$ CARVALHO, 1990, p.18.

${ }^{55}$ PERROT, 1988, p.121.
} 
pudessem pagar pela vivência na região central, visto que desejavam, também, participar da vida social da cidade luz, cujos atrativos maiores ocorriam nas regiões de disputa referidas por Perrot (1988). Vale salientar que autora identifica a ideia de "zona" no estudo referido, porém, há época, o termo significava local de pouca ou quase nenhuma dignidade; obviamente se referindo às pessoas que ali moravam, pertencentes às classes mais humildes.

O Brasil também foi espaço de práticas urbanas contraditórias, em consonância com as práticas francesas, por exemplo. Um processo sócio-histórico trágico, mas que exemplifica essa proximidade, ocorreu no Rio de Janeiro, inciado pela municipalidade de Barata Ribeiro, na destruição de um enorme cortiço localizado em área central da cidade: o Cabeça-de-porco ${ }^{56}$, esse acontecimento retrata a tentativa de modificar os espaços ocupados pelos mais pobres na Capital do país na República Velha, e que foi acelerado e intensificado na administração municipal de Pereira Passos.

Esse contexto foi explorado pelo historiador Sidney Chalhoub (1996), principalmente acerca da relação higienista entre pobreza, epidemias e destruições de cortiços na capital imperial do Brasil. O autor aborda o engendramento das articulações do poder municipal carioca, vinculado aos interesses de grupos da elite econômica, porém não deixa claro se essa conjuntura estava normatizada por leis de zoneamento. Aparentemente, havia elementos reguladores que favoreciam as práticas de discriminação espacial, mas sem alusão à nomenclatura referida. Mas, além da alta qualidade da obra, o autor elucida um aspecto fundamental do contexto carioca entre a população pobre, o centro urbano e a legislação, na virada do século XX:

Estavam-se engendrando os instrumentos legais para a guerra de extermínio contra os cortiços ou - o que dá quase no mesmo - para a política de expulsão das 'classes pobres'/'classes perigosas' das áreas centrais da cidade $^{57}$.

O contexto acadêmico do tema zoneamento, para a realidade brasileira, é diversificado. Flávio Villaça (2015), por exemplo, afirma a gênese do fenômeno já no século XIX, dimensionando que a questão era realizada sem pouca atividade intelectual, mas estritamente vinculada aos interesses de grupos elitistas:

O zoneamento - ao contrário do planejamento urbano scricto sensu - surge no Brasil sem qualquer elaboração teórica, sem a participação de intelectuais estudiosos da cidade e sem a influência do pensamento estrangeiro. Recorde-se que no final do século XIX, quando se inicia no Brasil, o zoneamento mal ensaiava os primeiros passos na Alemanha e nos Estados

\footnotetext{
${ }^{56} \mathrm{VAZ}, 1986$.

${ }^{57}$ CHALHOUB, 1996, p.34.
} 
Unidos. O que se inicia no Brasil corresponde (e continuará correspondendo) a interesses e soluções específicos das elites brasileiras. Mesmo recentemente, na maioria dos planos diretores brasileiros o zoneamento aparece apenas como princípios vagos e não operacionais. Ao contrário, as leis específicas de zoneamento, separadas dos planos diretores são operacionais, aprovadas nas Câmaras Municipais e executadas (evidentemente com os percalços da execução de tantas leis no Brasil). ${ }^{58}$

Essa interpretação é de grande utilidade, pois demonstra a complexidade do assunto. Tal característica dificulta o apontamento específico da gênese da regulamentação normativa da divisão do espaço da cidade em zonas; situa a questão em uma configuração de ocorrências não racionais de delimitação, aparentando-se ser uma opção momentânea e não planejada de diferenciação social.

Em uma dissertação de mestrado, defendida por Marília Borges (2007) na área de planejamento urbano na UFRJ, o assunto do zoneamento considerou o diálogo de Villaça (2015), e acrescentou dados importantes ao debate, por clarificar legislações que a autora considera como referências ao surgimento de leis de zoneamento no país. No caso, apresenta uma legislação carioca de 1918 e uma paulistana de 1929:

Outra referência ao surgimento do zoneamento no Brasil, é a partir do final da década de 1910, quando se deu a utilização dessa normatização urbanística, através da divisão da cidade em zonas diferenciadas quanto ao uso do solo e à volumetria das edificações, categorizadas, de acordo com o ordenamento e a evolução urbana, pelos novos Regulamentos de Construção aprovados para os principais centros brasileiros. No Rio de Janeiro, então Distrito Federal, foi estabelecido pelo Prefeito Amaro Cavalcanti, o Decreto no 1.185, de 5 de janeiro de 1918 que fixou as três zonas: urbana, suburbana e rural. Em São Paulo, a Lei no 3.427, de 19 de novembro de 1929, mais conhecido como Código Saboya, estabeleceu o primeiro zoneamento urbanístico propriamente dito. Os regulamentos de construção da década de 1920 possibilitaram a transformação do espaço urbano ao introduzirem em suas determinações o zoneamento urbanístico, onde a cidade foi dividida em áreas (zonas) diferenciadas por sua normalização. ${ }^{59}$

Acerca da realidade paulistana, relacionada à temática do zoneamento, é importante mencionar a pesquisadora Sarah Feldman (2013), que, mesmo com um recorte delimitado entre 1947-1961 $1^{60}$ configurando-se em datações posteriores à proposta deste trabalho - merece destaque, tanto pela profundidade do assunto abordado, quanto pela proximidade da temática envolvida.

\footnotetext{
58 VILLAÇA, 2015, p.178.

59 BORGES, 2007, p.64.

60 FELDMAN, 2013.
} 
Com essas características apresentadas é possível deduzir que o fenômeno urbanístico da divisão do perímetro urbano sorocabano é peculiar à situação nacional, devendo ser pormenorizado de formas complexas e diversas, sendo esta pesquisa apenas uma pequena contribuição para o debate em questão. Dessa forma, é importante registrar que este trabalho não esgota a temática acerca da gênese das leis de zoneamento no Brasil, muito menos induz hierarquizações epistemológicas. Apenas traz novos dados que podem servir a outras contribuições acadêmicas, que tenham a finalidade de analisar os momentos iniciais da história urbana republicana nacional.

\section{CONCLUSÃO}

O percurso utilizado considerou as regulamentações constitucionais para o Brasil (1891), bem como para o Estado de São Paulo (1891), enquanto elementos propulsores à autonomia da entidade municipal, principalmente acerca da independência administrativa; uma reivindicação do Partido Republicano desde finais do Império. No caso paulista, a autonomia consistia em uma "dependência", visto que cabia ao Estado a dimensionalidade da liberdade de gerência municipal.

Em termos de arrecadação, o governo paulista regulamentou - em legislação específica (1906) - a taxação de impostos de indústria e profissão, predial urbano e viação como dispositivos, entre outros, de acumulação de rendas que serviriam às municipalidades. Nesse sentido, foi analisada a situação de Sorocaba na utilização dessa dinâmica republicana institucionalizada. A partir de 1914, o município já estava padronizado aos dispositivos normativos estabelecidos pelas codificações estaduais, mediante normalização local (1914/1915). Nessa perspectiva, buscou-se compreender como foram utilizados os mecanismos institucionais na gerência e distribuição de recursos públicos, como água encanada, esgoto e iluminação; constatou-se a existência de um interessante e complexo vínculo com a regulamentação de Impostos de Viação.

Sendo assim, este trabalho abordou aspectos da distribuição de água, esgoto e iluminação pública em Sorocaba no início do século XX, utilizando-se de fontes documentais da Câmara Municipal que permitissem compreender a respectiva dinâmica desses recursos. Dessa forma foi possível identificar, em 1914, uma legislação de zoneamento no município; a fim de estabelecer o que pertencia ao perímetro urbano, bem como as regiões rústicas. Constatou-se que a distribuição dos recursos estavam basicamente polarizadas no perímetro oficializado, corroborado pelas configurações e aproximações entre leis municipais e cobranças de impostos entre 1914 e 1916, sob o plano das análises contidas neste trabalho. 
Essa distinta e peculiar situação adiciona novos olhares ao debate acerca da distribuição de recursos públicos para a cidade de Sorocaba do início do século XX, bem como busca estimular novos olhares acerca das normatizações legislativas da questão do zoneamento urbano no Brasil.

\section{REFERÊNCIAS}

ALMEIDA, Aluísio de. Sorocaba: 3 séculos de história. Itu: Editora Ottoni, 2002.

BARATA, Rita de Cássia Barradas. Epidemias. Cad. Saúde Pública, Rio de Janeiro, v. 3, n. 1, Mar, 1987. Available from: http://www.scielo.br/scielo.php?script=sci_arttext\&pid=S0102311X1987000100002\&lng=en\&nrm=iso>. Access on 01 Nov. 2014. http://dx.doi.org/10.1590/S0102-311X1987000100002

BORGES, Marília Vicente. O zoneamento na cidade do Rio de Janeiro: gênese, evolução e aplicação. Dissertação de Mestrado - UFRJ. Rio de Janeiro, 2007. Disponível em: http://www.ippur.ufrj.br/download/pub/MariliaVicenteBorges.pdf

CARMO, Jefferson Carriello do. Indústria têxtil, movimento operário e a questão das greves na cidade de Sorocaba. In: SIMPÓSIO NACIONAL DE HISTÓRIA, 24. 2007, São Leopoldo, RS. Anais do XXIV Simpósio Nacional de História - História e multidisciplinaridade: territórios e deslocamentos. São Leopoldo: Unisinos, 2007. CD-ROM. Disponível em: http://anpuh.org/anais/wpcontent/uploads/mp/pdf/ANPUH.S24.0373.pdf

CARVALHO, José Murilo de. Os bestializados: O Rio de Janeiro e a República que não foi. São Paulo: Companhia das Letras, 1987. 1990.

A formação das almas: o imaginário da República no Brasil. São Paulo: Companhia das Letras,

CARVALHO, Rogério Lopes Pinheiro de. Discursos do progresso e persistência da tradição: a remodelação urbana de Sorocaba (1914-1921/1938-1943). In: Politeia: História e Sociedade, vol.6 n. 1 2006. Acesso disponível em: http://periodicos.uesb.br/index.php/politeia/article/view/212/234

Fisionomia da cidade: Sorocaba-cotidiano e desenvolvimento urbano (1890-1943). Tese de Doutorado - IFCH/USP. São Paulo, 2008.

CELLI, Andressa. Evolução urbana de Sorocaba. Dissertação - FAUUSP. São Paulo, 2012. Acesso disponível em: http://www.teses.usp.br/teses/disponiveis/16/16139/tde-27072012141358/en.php

CHALHOUB, Sidney. Cidade febril: cortiços e epidemias na Corte imperial. São Paulo: Companhia das Letras, 1996.

CHARTIER, Roger. A história ou a leitura do tempo. 2. ed. Belo Horizonte: Autêntica Editora, 2010.

COELHO, Sergio. Os espanhóis. Sorocaba: TCM, 2002. 
ELIAS, Norbert; SCOTSON, John. Os estabelecidos e os outsiders: sociologia das relações de poder a partir de uma pequena comunidade. Rio de Janeiro: Zahar, 2000.

FAORO, Raymundo. A aventura liberal numa ordem patrimonialista. Revista Usp, n. 17, p. 14-29, 1993. Acesso disponível em: http://www.revistas.usp.br/revusp/article/view/25950/0

FELDMAN, Sarah. O zoneamento ocupa o lugar do plano: São Paulo, 1947-1961. Anais: Encontros Nacionais da ANPUR, v.7, p. 667-684, 2013.

FOUCALT, Michel. Microfísica do poder. Rio de Janeiro: Graal, 1979.

GASPAR, Antônio Francisco. Minhas memórias: Sorocaba - São Paulo - Santos e Viceversa período 1896 a 1909. Sorocaba: Editôra Cupolo, 1967.

GROAT, L. N.; WANG, D. Architectural research methods. 2. ed. Hoboken, NJ: Wiley, 2013. Disponível em: https://onlybooks.org/architectural-research-methods-2nd-edition-44097.

MASSARI, Marco Antônio Leite. Arquitetura industrial em Sorocaba: o caso das fábricas têxteis. Dissertação - FAUUSP. São Paulo, 2011. Acesso disponível em: http://www.teses.usp.br/teses/disponiveis/16/16133/tde-13012012-113516/en.php

PERROT, Michelle. Os excluídos da história: operários, mulheres e prisioneiros. Rio de Janeiro: Paz e Terra, 1988.

SALES, João Alberto. A pátria paulista. Brasília: Editora Universidade de Brasília, 1983.

SANDANO, Wilson; FERREIRA, Valdelice Borghi. Educação Escolar e Movimentos Sociais em Sorocaba, no início da República. Campinas: Revista HISTEDBR On-line, n.27, p.172-178, 2007.

SCHWARCZ, Lilia Katri Moritz. O Espetáculo das raças. 8 edição. 7. ed. São Paulo: Companhia das Letras, 2007.

SILVA, Maria Vieira da (org.). Almanach de Sorocaba para 1903. Ed. Fac-similar - Taquarituba: Nassib Stefano, 2007.

SPENCER, Herbert,1820-1903. A justiça. Versão de Augusto Gil. Rio de Janeiro: Francisco Alves, 1891.

STRAFORINI, Rafael. No caminho das tropas. Sorocaba: TCM, 2001.

VAZ, Lílian Fessler. Notas sobre o Cabeça de Porco. Revista do rio de Janeiro, v. 1, n. 2, p. 29-35, 1986.

VILLA, Marco Antonio. A história das constituições brasileiras. São Paulo: Leya, 2011.

VILLAÇA, Flávio. Uma contribuição para a história do planejamento urbano no Brasil. In: O processo de urbanização no Brasil. 2.ed. 1. reimpr. São Paulo: Editora da Universidade de São Paulo, 2015.

WERNECK, Bráulio (org.). Almanaque Illustrado de Sorocaba: repositório histórico, literário e recreativo com ilustrações (1914). Ed fac-similar. Taquarituba: Juracy Tenor, 2006. 
WEY NETTO, Otto. Homens que fizeram nossa história. Sorocaba: TCM Comunicação, 2015.

\section{Constituições, códigos e leis}

BRASIL. Constituição da República dos Estados Unidos do, de 24 de Fevereiro de 1891. Disponível em: http://www.planalto.gov.br/ccivil_03/Constituicao/Constituicao91.htm

Codificação das Leis da Camara Municipal de Sorocaba. São Paulo: Duprat \& Comp., 1906. (1914-1915). Sorocaba: Typographia Quinze de Novembro, 1915.

SÃO PAULO. Constituição do Estado de, 1891. Disponível em: http://www.al.sp.gov.br/leis/constituicoes/constituicoes-anteriores/constituicao-estadual-1891/ Lei N. 16, de 13 de Novembro de 1891. Disponível em: http://www.al.sp.gov.br/repositorio/legislacao/lei/1891/lei n.16, de 13.11.1891.pdf

Decreto N. 86, de 29 de Julho de 1892. Disponível em: http://www.al.sp.gov.br/repositorio/legislacao/decreto/1892/decreto-86-29.07.1892.html

Lei N. 1.038, de 19 de dezembro de 1906. Dispõe sobre a organização municipal. Diario Official do Estado de São Paulo. São Paulo, n. 17 de 20 de janeiro de 1907. Disponível em: http://dobuscadireta.imprensaoficial.com.br/default.aspx?DataPublicacao=19070120\&Caderno=Di ario Oficial\&NumeroPagina $=221$

\section{Acervos consultados}

Museu Histórico Sorocabano (Secretaria da Cultura - Secult):

Camara Municipal de Sorocaba - Lançamento do Imposto Predial Rustico - Ano 1916 - Livro 438. Lançamento do Imposto de Viação - Ano 1916 e 1917 - Livro 439. Lançamento do Imposto Predial Urbano - Ano 1916 - Livro 436.

Gabinete de Leitura Sorocabano

\section{Acervo virtual}

http://www.cdpb.org.br/dic_bio_bibliografico_sales joao.html

Trabalho enviado em 09 de outubro de 2015.

Aceito em 05 de dezembro de 2015. 